\title{
Phosphate speleothems in caves developed in iron ores and laterites of the Carajás Mineral Province (Brazil) and a new occurrence of spheniscidite
}

\author{
Alan R.L. Albuquerque ${ }^{1 *}$, Rômulo S. Angélica ${ }^{1}$, Daniele F. Gonçalves ${ }^{2}$, and Simone P.A. Paz ${ }^{1}$ \\ ${ }^{1}$ Laboratório de Caracterização Mineral-LCM, Instituto de Geociências, Universidade Federal do Pará-UFPA. Rua Augusto Corrêa, 01, Guamá, Caixa \\ Postal 479, Belém, Pará, Brasil \\ ${ }^{2}$ Gerência de Meio Ambiente Ferrosos Norte-Vale. Rua Guamá, 60, Núcleo Urbano de Carajás, Parauapebas, Pará, Brasil
}

\begin{abstract}
The Carajás Mineral Province has one of the largest concentrations of caves in Brazil, and its iron ore is among the country's main exports. As a result of iron ore intense extraction, new environmental policies have been implemented. In an attempt to balance economic activity and environmental conservation, an inventory and a relevance-based classification of caves were implemented in 2008 as criteria for environmental licensing of mining ventures. This implementation motivated the present study of phosphate speleothems in Carajás' caves developed in ferriferous rocks. The objectives of this study are to describe the phosphate minerals and their formation processes based on geochemical and petrographic analysis, X-ray powder diffraction (XRD), differential scanning calorimetry coupled with thermogravimetry (DSC-TG), Fourier-transform infrared (FTIR) and scanning electron microscopy (SEM). Eight caves were selected for this study, along the slopes of the plateaus from Carajás. The phosphate speleothems usually present compositional zoning, with strengite-phosphosiderite in the core and leucophosphite-spheniscidite on the edges. This zoning cannot be related to leucophosphite-spheniscidite decomposition, since the DSC-TG curves show that dehydroxylation and loss of $\mathrm{NH}_{3}$ from leucophosphite-spheniscidite require temperatures higher than $250^{\circ} \mathrm{C}$. FTIR results allowed us to identify the $\mathrm{NH}_{4}$ functional group, based on absorbance bands at 1,430 and $3,040 \mathrm{~cm}^{-1}$, which associated to other data confirm the presence of spheniscidite. Refined values of the unit cell parameters for spheniscidite $\left(a=9.803 \AA, b=9.722 \AA, c=9.858 \AA, \beta=102.78^{\circ}\right)$ obtained using the Rietveld refinement, were slightly lower than those of the ICSD-39654 file. These smaller values are attributed to increasing substitutions of $\mathrm{K}^{+}$for $\mathrm{NH}_{4}{ }^{+}$, and $\mathrm{Al}^{3+}$ for $\mathrm{Fe}^{3+}$. Based on the geochemical analysis, significant enrichment in $\mathrm{P}_{2} \mathrm{O}_{5}, \mathrm{Zn}, \mathrm{Ni}$, and $\mathrm{Rb}$ was detected in phosphate speleothems, and phosphatized laterite, suggesting that bat guano was a potential source of these elements.
\end{abstract}

Keywords: $\quad$ cave, iron ore, phosphate speleothems, spheniscidite, Carajás

Received 23 May 2017; Revised 22 November 2017; Accepted 25 November 2017

Citation: $\quad$ Albuquerque A.R.L., Angélica R.S., Gonçalves D.F. and Paz S.P.A., 2018. Phosphate speleothems in caves developed in iron ores and laterites of the Carajás Mineral Province (Brazil) and a new occurrence of spheniscidite. International Journal of Speleology, 47 (1), 53-67. Tampa, FL (USA) ISSN 0392-6672 https://doi.org/10.5038/1827-806X.47.1.2135

\section{INTRODUCTION}

The caves in the Carajás Mineral Province, southeastern Pará State (Brazil), developed at the interface between a lateritic crust and saprolite rock belonging to the Grão-Pará Group (jaspilite and associated mafic rocks). These caves are typically present in or around iron ore mining areas at the Carajás Mineral Province, which is world's one of the largest mineral provinces of $\mathrm{Fe}$ and has one of largest concentration of caves in Brazil (Parker et al., 2013a; Piló et al., 2015).

Although the caves developed in ferriferous rocks of Carajás represent a unique minerogenic area that differs from typical carbonate rocks, these caves can also be regarded as a karst system due to their dissolution features, such as those described by Simmons (1963) in the Quadrilátero Ferrifero, Minas Gerais State, Brazil. According to the classification system presented by Gillieson (1996), karst terrains and their caves develop not only in carbonate and evaporite rocks but also in arenite, basalt, granite, and laterite.

Axelrod et al. (1952) published a relevant report on caves developed in ferriferous rocks and described caves in solid iron ore at Montes Bomi, northwestern Liberia. In Brazil, pioneer studies of caves developed 
in iron ore and associated rocks were carried out by Simmons (1963) at the Quadrilátero Ferrifero, Tolbert et al. (1971), and Maurity \& Kotschoubey (1995) at Serra dos Carajás, southeastern Pará State.

Initially, formation and ecosystems studies of cave in ferriferous rocks were performed only for scientific purposes. In 2008, following a Brazilian Decree 6.640, the inventorying and relevance-based classification of these ecosystems became criteria for environmental licensing of mining ventures (Auler \& Piló, 2015).

Maurity \& Kotschoubey (1995) identified speleothems composed of $\mathrm{Fe}$ and $\mathrm{Al}$ oxide-hydroxides, sulfates and phosphates in caves on Serra Norte, Carajás. These authors described leucophosphite $\left[\mathrm{KFe}_{2}\left(\mathrm{PO}_{4}\right)_{2} \mathrm{OH} \cdot 2 \mathrm{H}_{2} \mathrm{O}\right]$, strengite, and phosphosiderite $\left(\mathrm{FePO}_{4} \cdot 2 \mathrm{H}_{2} \mathrm{O}\right.$ polymorphs) as the most abundant minerals composing these cave's speleothems, which are present on cave walls, floors and ceilings as stalactites, stalagmites, crusts and coralloids.

The formation of these phosphate minerals in cave ecosystems has been attributed to interactions between bat guano and the surrounding rocks (Axelrod et al., 1952; Simmons, 1963; Simmons, 1964; Bridge, 1973; Maurity \& Kotschoubey, 1995; Onac \& Vereş, 2003; Giurgiu \& Tămaş, 2013; Sauro et al., 2014; Wurster et al., 2015). However, the formation, evolution, and geochemical signature of guano in these phosphate minerals in the Carajás' caves have not been previously discussed.

The speleothems from the Carajás' caves were investigated with the objective of identifying phosphate minerals and their origin based on data from geochemical and petrographic analysis, X-ray powder diffraction (XRD), differential scanning calorimetry coupled with thermogravimetry (DSC-TG), Fouriertransform infrared spectrometry (FTIR), and scanning electron microscopy (SEM). In addition, our goals were to contribute to the literature on caves developed in iron ore and laterite, whose formation and evolution are poorly understood, and to provide new perspectives for future studies of karst environments in iron ores, given that these systems can be points of conflict between mining and speleological conservation.

\section{GEOLOGICAL AND GEOMORPHOLOGICAL SETTING}

The Serra Norte geomorphologic unit (North Ridge) is represented by several plateaus, named in a sequence, beginning with $\mathrm{N}$ (North): N1, N2, N3, N4, N5, N6, N7, and N8. The eight caves studied in this work are located along the slopes of N4 and N5 plateaus, where iron ore exploitation is in progress (Fig. 1). The Serra Norte is located in the residual hills of Serra dos Carajás, southwestern Pará State, Brazil (Fig. 1). The Serra dos Carajás' plateaus are part of the Planalto Dissecado do Sul do Pará and are believed to be partly planation surfaces resulting from Pliocene pediplanation and partly ancient Cretaceous or pre-Cretaceous pediplains (Boaventura et al., 1974). The Planalto Dissecado do Sul do Pará is characterized by residual hills with flat tops and groups of peaks and crests interspersed among low lying terrain (Boaventura et al., 1974).

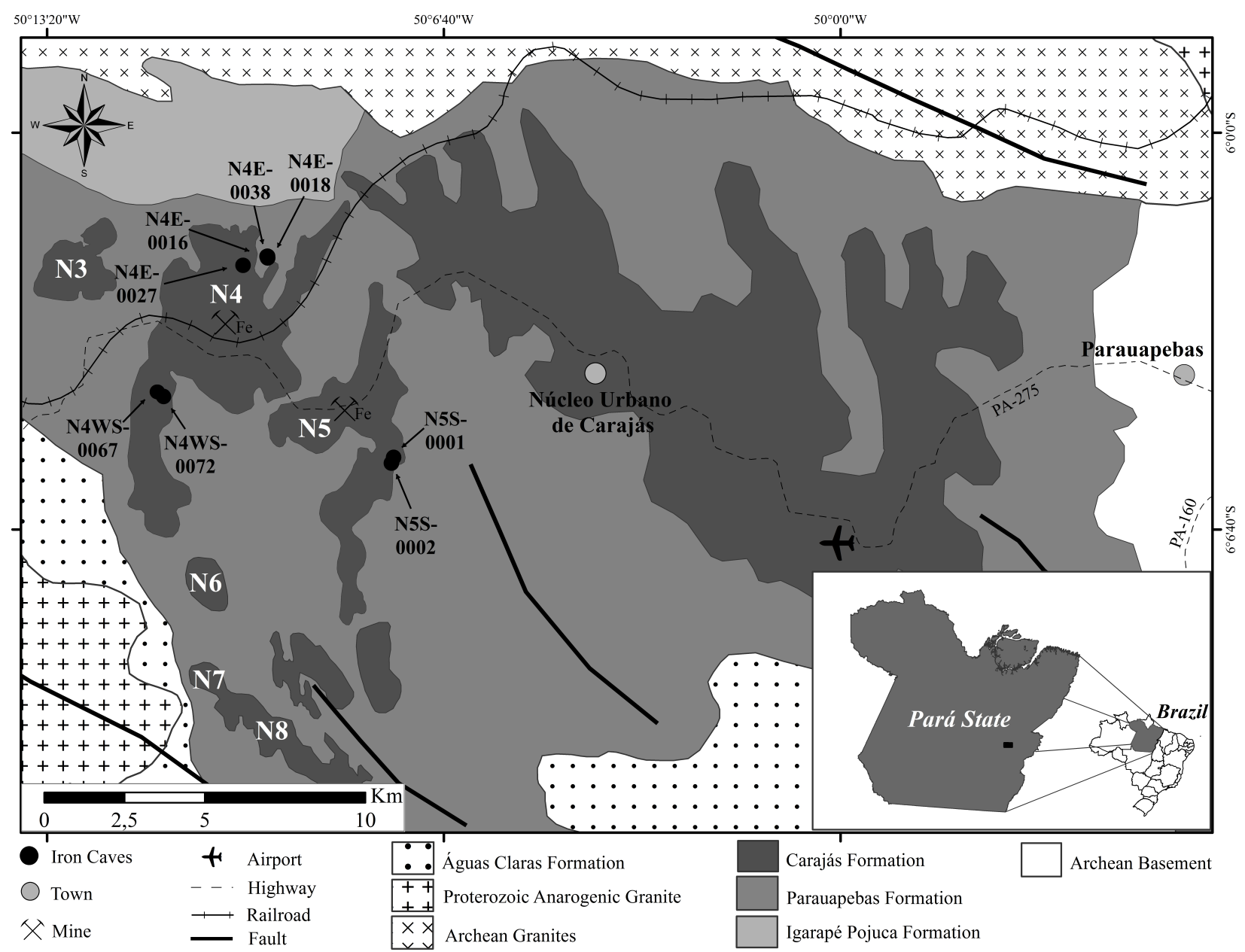

Fig. 1. Simplified geological map showing the locations of the caves from this study (modified from Vasquez et al., 2008). 
The Serra Norte is underlain by thick lateritic crust (probably Late Cenozoic), developed on Neoarchean rocks belonging to the Grão-Pará Group (Maurity \& Kotschoubey, 1995; Macambira, 2003). This group consists of metabasalt from Parauapebas Formation and banded iron formations (BIF) from Carajás Formation (Tolbert et al., 1971; Maurity \& Kotschoubey, 1995; Macambira, 2003; Piló \& Auler, 2009; Parker et al., 2013a; Piló et al., 2015). These rocks influence the overlying lateritic crust formed on them, both chemical composition and texture, as well as in the supply of Fe and Al to the formation of speleothems, as follow: 1) an aluminous iron crust with spherulitic texture, derived from metavulcanic rocks; and 2) a hematite crust with breccioid texture, originated from the weathering of iron formations (Maurity \& Kotschoubey, 1995).

The interface between the lateritic crust and the saprolite of the Grão-Pará rocks represents the most suitable horizon for cave development, where low density zones correspond to layers with high permeability and porosity (Simmons, 1963; Maurity \& Kotschoubey, 1995; Piló \& Auler, 2009).

According to Maurity and Kotschoubey (1995), the formation of Carajás' caves could be related to supergene processes. The Fe, Al, and Si mobilization and redistribution in the lateritic crust caused the formation of porous and permeable zones that due to erosion and dissolution formed the halls and galleries of the caves. Another possibility for caves formation in iron rocks could be by microbial action (McFarlane and Twidale 1987; Parker et al., 2013b). Parker et al. (2013a) identified microbial species and pendulous biofilms inside Carajás' caves. Some of these species are recognized as responsible for iron oxidation and reduction processes.

The Carajás' caves are small in size, in average of $33 \mathrm{~m}$. Structural control is most apparent in the caves developed in BIF. Drainage channels and temporary pools occur through the concentration of drip or percolation of rainwater infiltrated through small conduits or geological discontinuities. Most of the caves are connected to the hydrological system of the modern slopes, generating an irregular subsurface flow, however, without interconnection between them. The percolation of water in caves depends on the rock porosity and their proximity to the surface. As Carajás' caves are shallow, the water flow is significant only during the rainy season (Piló et al., 2015).

According to Maurity and Kotschoubey (1995), the speleothems formation could be related to the last evolutional stage of the caves, caused by dissolution and reprecipitation processes. These deposits are composed of oxide-hydroxides, sulfates, and phosphates of $\mathrm{Fe}$ and/or $\mathrm{Al}$, which constitute floor, wall, and ceilings coating in the form of crusts, coralloids, stalactites, and stalagmites.

\section{Caves of N5 Plateau}

Caves N5S-0001 and N5S-0002 are located in the middle of N5 Plateau (Figs. 1 and 2a, b), at the interface between the jaspilite saprolite and the lateritic crust. Jaspilite saprolite with leached silica bands is present locally, exposing its primary structure, which is characterized by alternating bands of jasper and iron oxide-hydroxides (hematite and/or goethite). The lateritic crust exhibits a porous texture, a breccioid aspect, and is composed of angular jaspilite clasts cemented by iron oxide-hydroxides (Fig. 2c). The speleothems exhibit crust and coralloid forms of millimetric thickness (Fig. 2c, d). Small colonies of bats are present in the caves.

\section{Caves of N4 Plateau}

The caves of N4 Plateau were divided into two groups: those on the east side (N4E) and those on the southwest side (N4WS). Caves N4E-0016, N4E0018, N4E-0027, and N4E-0038, on the east side (Figs. 1 and $3 \mathrm{a}-\mathrm{d}$ ), developed at the interface between the lateritic crust and the jaspilite saprolite. The saprolite shows the preserved relict structure of the original rock, with locally preserved jaspilite portions (Fig. 3e). The lateritic crust displays breccioid aspect and porosity controlled by the jaspilite lamination orientation and is composed of angular jaspilite clasts cemented by iron oxide-hydroxides. The speleothems occur as crust and coralloid of millimetric thickness (Fig. 3e). Few bats were observed.

Caves N4WS-0067 and N4WS-0072 are located on the southwest side of N4 Plateau (Figs. 1 and 4a, b) within the lateritic crust. The lateritic crust displays a porous texture with a breccioid aspect and is composed of angular jaspilite fragments surrounded locally by phosphate material, creating phosphatized laterite (Fig. 4c). Compare to other caves described in this study, in both N4WS cavities, the speleothems are well developed and contain a greater variety of speleothems, particularly stalactites, stalagmites, crusts, and coralloids. These speleothems are located along the walls and cover the cave floors and ceiling (Fig. 4c). On the floor of Cave N4WS-0067, ravines typically deeper than $2 \mathrm{~m}$ and paleofloors were observed (Fig. 4d). These caves contain colonies with hundreds of bats and guano accumulations a few centimeters thick.

\section{MATERIALS AND METHODS}

Thirty-three samples were collected from 8 caves located on N4 and N5 plateaus (Fig. 1). The samples consisted of 5 phosphatized laterite samples, 14 lateritic crust and jaspilite saprolite samples, and 14 speleothem samples. Four speleothem samples were split into core and edges, generating 4 additional samples, for a total of 37 subsamples.

Textural and mineralogical features were characterized by analyzing 23 polished thin sections under a light microscope (LEICA model DM2700 P). In addition, 21 undisturbed fragments and 11 polished thin sections were analyzed by SEM (Zeiss model LEO 1430) coupled with point qualitative chemical analysis by energy dispersive spectroscopy (EDS). The SEM imaging was performed using the backscattered electron (BSE) and secondary electron (SE) techniques with a $90 \mu \mathrm{A}$ emission current, a $20 \mathrm{kV}$ constant accelerating voltage, a $15 \mathrm{~mm}$ working distance and a $30 \mathrm{~s}$ acquisition time. 

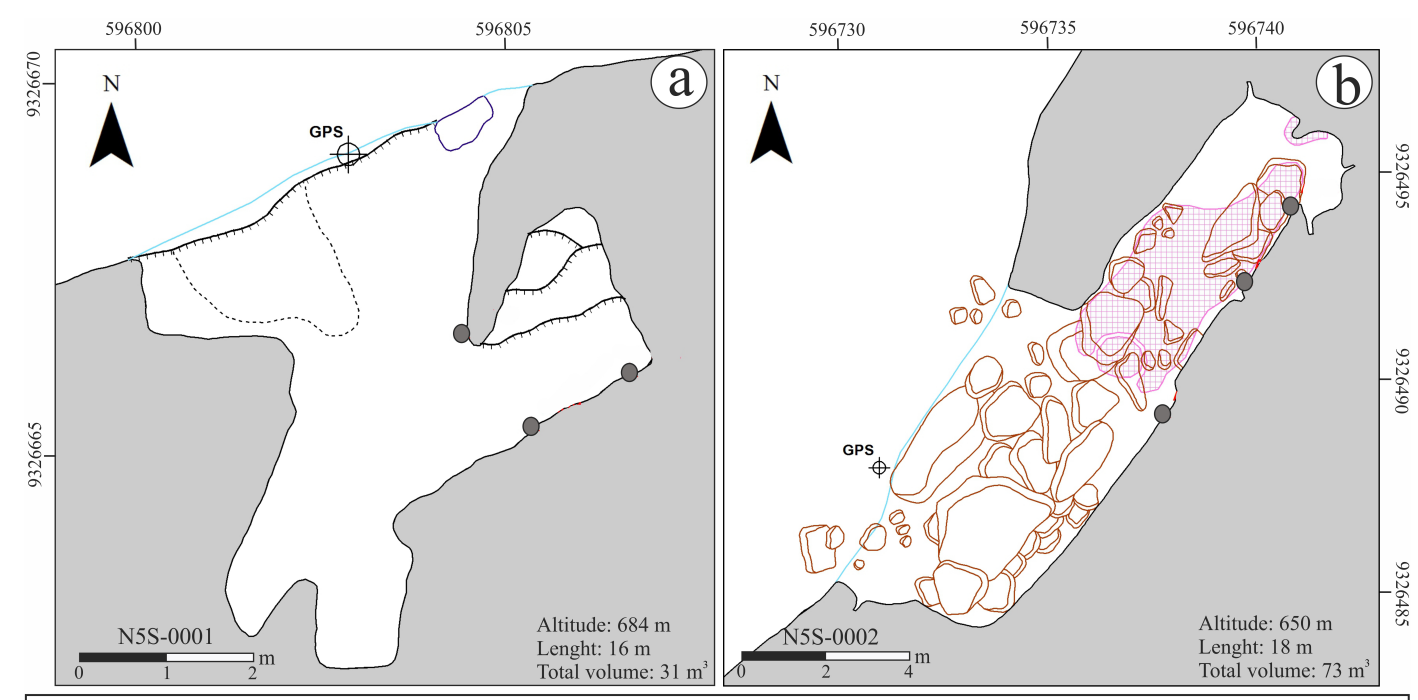

\begin{tabular}{|lll|}
\hline Sample & $\sim_{\text {External contour }} \sim_{\text {Waterline }}$ & Blocks, Pebble and gravel \\
Inferred contour $_{\text {Abrupt gap }}$ & $\square$ Speleotems site & Saprolite/Lateritic crust \\
\hline
\end{tabular}
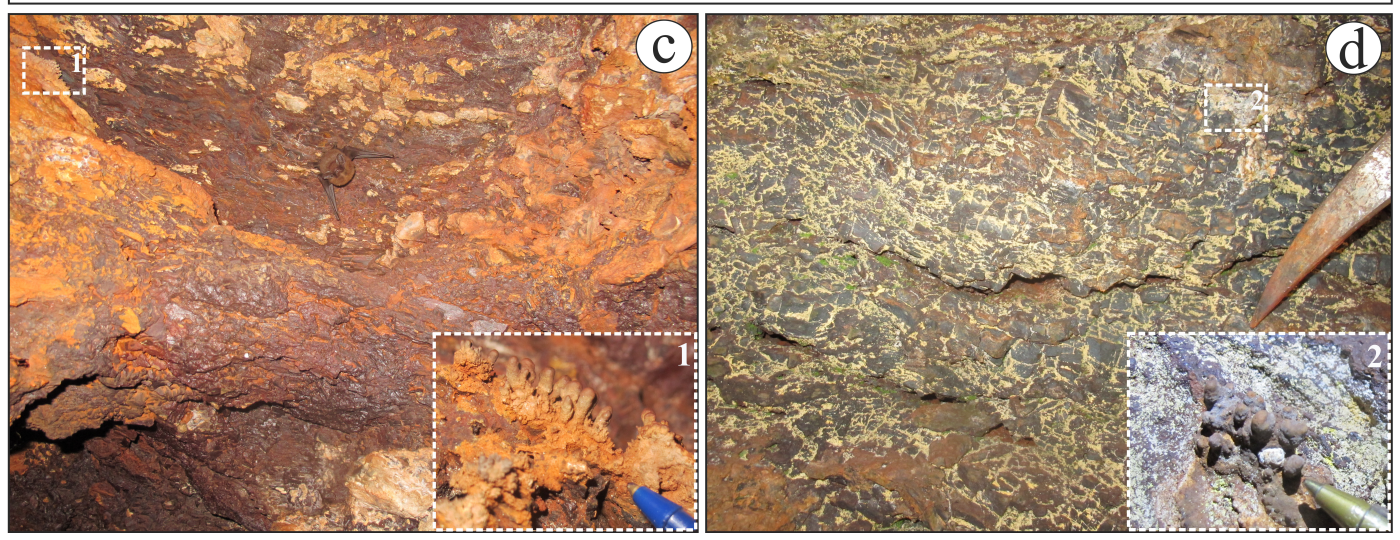

Fig. 2. Caves of the N5S Plateau. a-b) maps of caves N5S-0001 and N5S-0002, showing sampling sites; c) jaspilite saprolite with leached silica bands, and small coralloid composed of iron oxide-hydroxide and phosphates (inset 1 for details); d) breccioid lateritic crust with jaspilite clasts, and whitish iron phosphate crust and iron oxide-hydroxide coralloids (inset 2 for details).

Mineralogical identification was also performed by XRD analysis of 37 samples using the powder method. The diffractometer used was an Empyrean, from PANalytical equipped with a Co anode (Ka1 $1.790 \AA$ ) , a Fe $\mathrm{K} \beta$ filter, a $1 / 4^{\circ}$ divergence slit, a $1 / 2^{\circ}$ anti-scatter slit, and a $10 \mathrm{~mm}$ beam mask. A $0.02^{\circ}$ $2 \theta$ step size, $5^{\circ}$ to $75^{\circ}$ scanning at $2 \theta$, a $70.125 \mathrm{~s}$ step time, a $40 \mathrm{kV}$ voltage and a $40 \mathrm{~mA}$ current were used. The $\mathrm{LaB}_{6}$ NIST/SRM 660b standard was used to determine instrumental resolution. Data acquisition was performed with PANalytical X'Pert Data Collector software version 5.1 , and mineralogical identification was performed with PANalytical X'Pert HighScore Plus software version 4.0 using the PDF-ICDD database (Powder Diffraction File - International Center for Diffraction Data).

Structural calculation of spheniscidite $\left[\mathrm{NH}_{4} \mathrm{Fe}_{2}\right.$ $\left(\mathrm{PO}_{4}\right)_{2}(\mathrm{OH}) \cdot 2 \mathrm{H}_{2} \mathrm{O}$ l was performed using the Rietveld refinement method with FullProf v. 2011 software (Rodriguez-Carvajal, 1993) and a FULL v. 2012 graphic interface (Paz et al., 2012). Compound 39654 from the Inorganic Crystal Structure Database (ICSD) was used as an initial structural model for the spheniscidite (Yakubovich \& Dadashov, 1992).

DSC-TG measurements of 10 phosphate speleothem samples were conducted using a NETZSCH STA 449F3 Jupiter instrument equipped with a simultaneous thermal analyzer (NETStanton Redcroft Ltd.) and a vertical cylindrical platinum furnace operating in a temperature range of 25 to $1,000^{\circ} \mathrm{C}$ with a $50 \mathrm{ml} /$ min nitrogen flow rate and a heating rate of $10^{\circ} \mathrm{C} / \mathrm{min}$ and using a platinum cup as a reference. The product obtained after heating to $1,000^{\circ} \mathrm{C}$ was also analyzed by XRD.

FTIR spectra were obtained for 10 phosphate speleothem samples using a Thermo Spectrometer (model IR100), with a spectral range of 4,000 to 400 $\mathrm{cm}^{-1}$, using 64 scans with a $4 \mathrm{~cm}^{-1}$ resolution. The samples were prepared as pellets by mixing $5 \mathrm{mg}$ of sample with $150 \mathrm{mg}$ of $\mathrm{KBr}$. Based on the FTIR data, two samples representative of two phosphate groups (strengite-phosphosiderite and leucophosphitespheniscidite) were analyzed using a second spectrometer (Bruker, model Vertex 70) with a $4,000-400 \mathrm{~cm}^{-1}$ spectral range, using 16 scans and a $4 \mathrm{~cm}^{-1}$ resolution. The samples were dried at $110^{\circ} \mathrm{C}$ for 24 hours, followed by pellet preparation.

The chemical analysis was performed on 12 samples: 4 samples of phosphate speleothem (PS), 4 of phosphatized laterite (PL) and 4 of lateritic crust and jaspilite saprolite (LC/JS). The mean content of 62 samples of jaspilite (Macambira \& Schrank, 2002) was used for comparisons. The geochemical analysis was performed by a commercial laboratory (SGS 

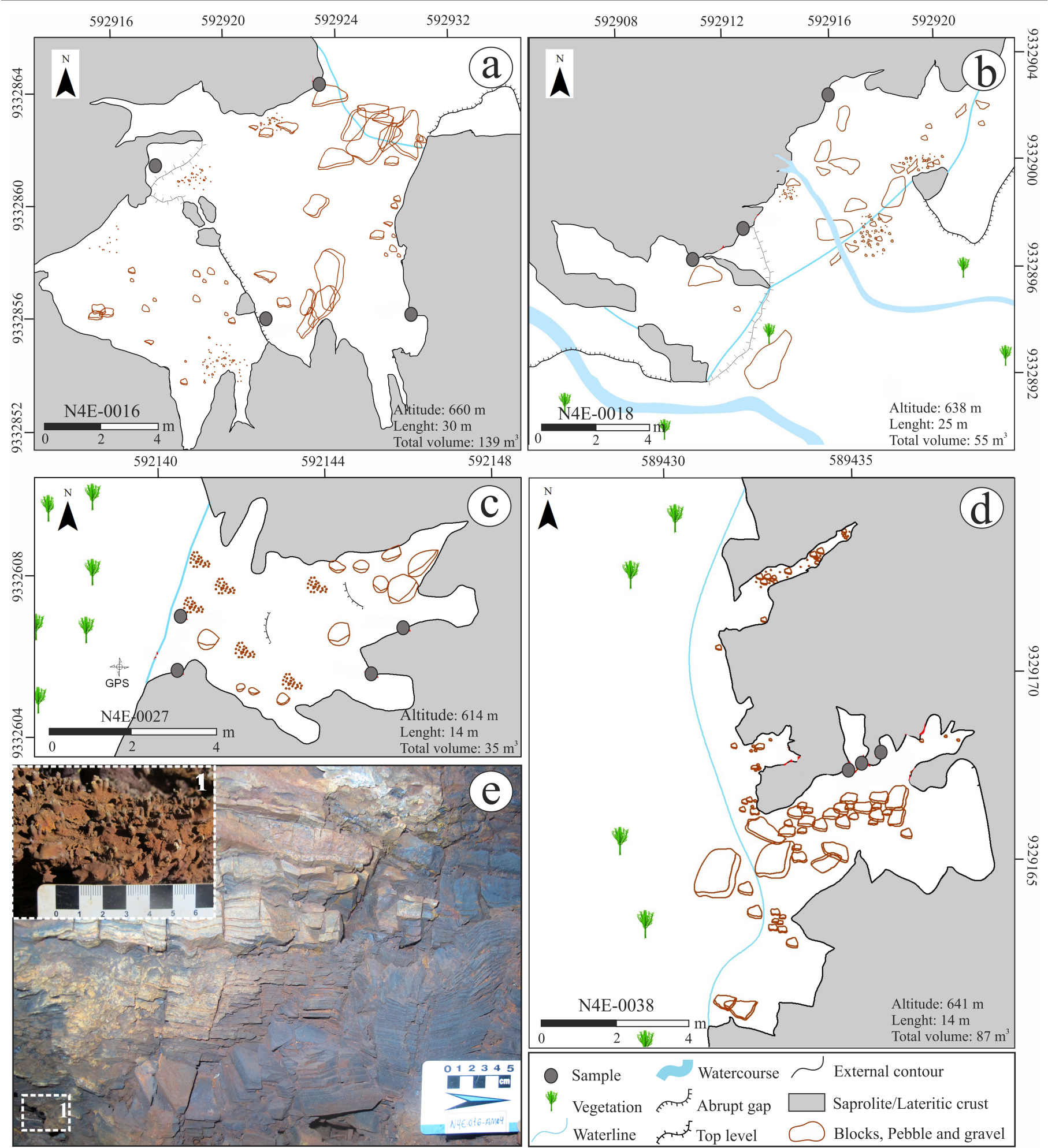

Fig. 3. Caves of the N4E Plateau. a-d) maps of caves N4E-0016, N4E-0018, N4E-0027, and N4E-0038, showing the sampling sites; e) slightly leached saprolite, and millimetric coralloids (inset 1 for details).

Geosol), the major and minor element concentrations were obtained by inductively coupled plasma optical emission spectroscopy (ICP-OES) using a Perkin Elmer equipment (model Optima 7300 DV), and trace elements and rare-earth elements (REEs) were determined by inductively coupled plasma mass spectrometry (ICP-MS) using a spectroscope Perkin Elmer Nex Ion 300X. Sample fusion was performed with lithium metaborate $\left(\mathrm{LiBO}_{2}\right)$ and dissolution with nitric acid $\left(\mathrm{HNO}_{3}\right)$, and tartaric acid $\left(\mathrm{C}_{4} \mathrm{H}_{6} \mathrm{O}_{6}\right)$. Loss-on-ignition (LOI) values were determined by calcination 2 grams of sample at $1,000^{\circ} \mathrm{C}$ for 1 hour. $\mathrm{Fe}_{2} \mathrm{O}_{3}$ and $\mathrm{P}_{2} \mathrm{O}_{5}$ concentrations exceeding 75 and $25 \%$, respectively, were determined by colorimetry using a Varian spectrometer (model Cary 50 UVVis); the same technique was used for determining the $\mathrm{NH}_{4}$ content in the 4 phosphate speleothem samples.

\section{RESULTS AND DISCUSSION}

\section{Evidence of phosphatization and mineralogical composition}

The most abundant speleothems in the Serra Norte' caves occur as crusts, coralloids stalactites, and stalagmites. Speleothems composed by iron oxide-hydroxides (hematite and goethite), and 
sulfate (alunite) occur commonly as crusts and coralloids, whereas iron phosphates (strengite, phosphosiderite, leucophosphite, and spheniscidite) constitute speleothems with larger sizes, as stalactites, stalagmites, as well as coralloids and crusts. Quartz and anatase occur as detrital minerals from caves' host rocks (Fig. 5).

Phosphate speleothems were more abundant in caves N4WS-0067 and N4WS-0072, which developed entirely in the lateritic crust and display thick guano accumulations. In these caves, the lateritic crust is composed of angular to sub-rounded jaspilite fragments and iron oxide-hydroxide nodules cemented by either crystalline or amorphous phosphate material. The edges of these fragments and nodules (Fig. 6a, b) and a few of the core of hematite pseudomorph after magnetite (Fig. 6c) are replaced by phosphorus occupying tetrahedral sites in the hematite structure (Gálvez et al., 1999).

The presence of phosphate minerals is attributed to phosphatization in which phosphoric acid, a product of guano decomposition, reacts with iron oxide-hydroxides, typically amorphous, to produce dissolution, and thereafter precipitation of iron phosphates. This process is entirely inorganic (Forti, 2001; Onac \& Vereş, 2003; Wurster et al., 2015).
For the formation of iron phosphates by precipitation in acidic conditions $\left(\mathrm{H}_{3} \mathrm{PO}_{4}\right)$ (Lima \& Reymão, 1983), the following reaction is suggested (Eq. 1):

$$
\mathrm{FeOOH}_{(\mathrm{s})}+\mathrm{H}_{3} \mathrm{PO}_{4(\mathrm{aq})} \rightarrow \mathrm{FePO}_{4} \cdot 2 \mathrm{H}_{2} \mathrm{O}_{(\mathrm{s})}
$$

The phosphate speleothems consist of stalactites, stalagmites, coralloids, and crusts. They are porous and commonly display laminated and concentric structures with core typically composed of strengite and phosphosiderite and edges made of leucophosphite and spheniscidite. These minerals occur as gray-whitish to pale yellow finely crystalline aggregates (Fig. 7a, b).

Light microscopy analysis indicates that these minerals do not exhibit textural differences, because they are present as aggregates of typically small associated crystals (Fig. 7c, d). Strengite and phosphosiderite can be differentiated by $\mathrm{XRD}$, given that they are $\mathrm{FePO}_{4} \cdot 2 \mathrm{H}_{2} \mathrm{O}$ polymorphs, whereas leucophosphite and spheniscidite (Fig. 7b) are isomorphs of the monoclinic, $P 2_{1} / n$ space group, and contain a solid solution of $\mathrm{K}^{+}$and $\mathrm{NH}_{4}{ }^{+}$, respectively (Wilson \& Bain, 1976). It was not possible to differentiate these minerals by SEM since

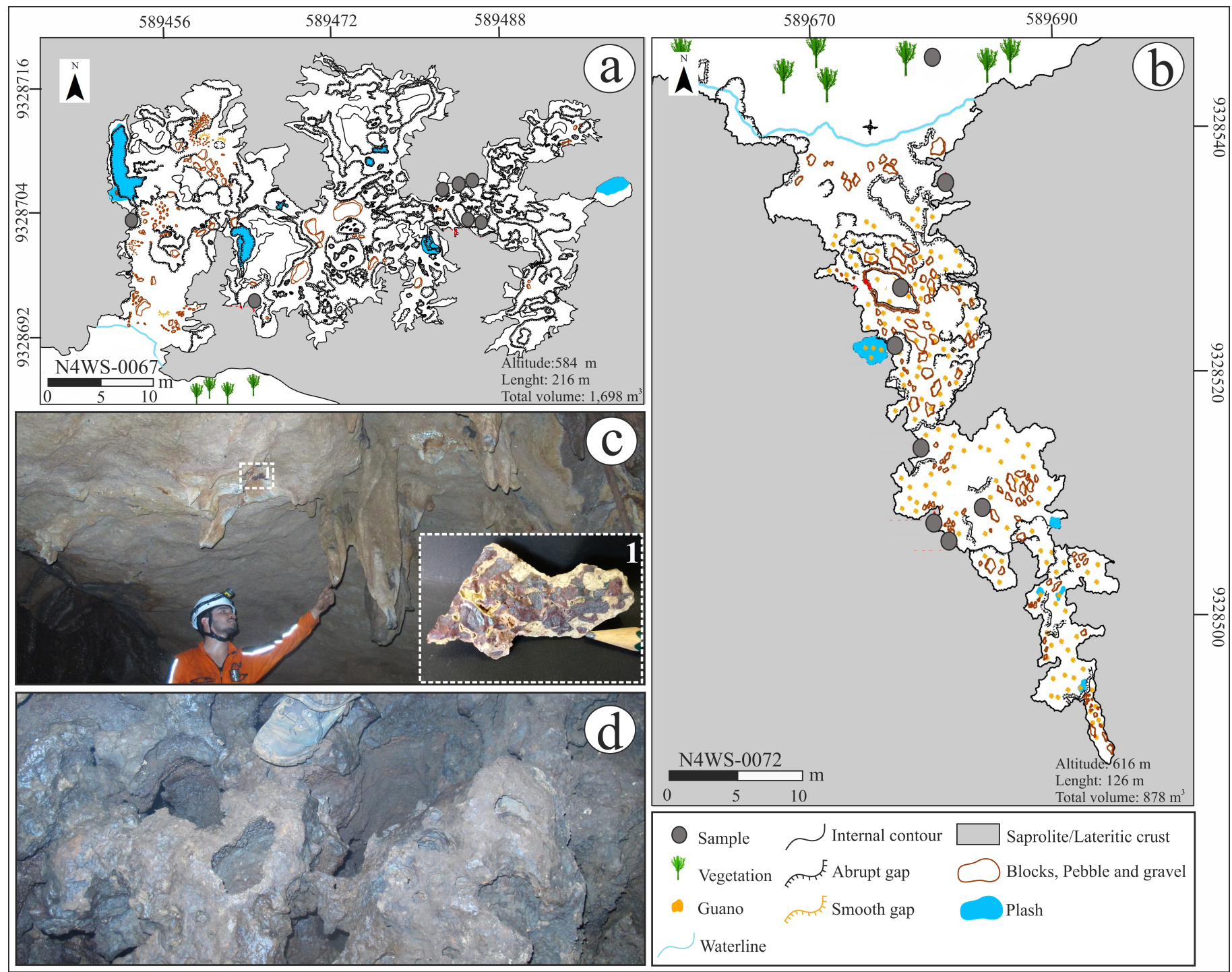

Fig. 4. Caves of the N4WS Plateau. a-b) maps of caves N4WS-0067 and N4WS-0072, displaying the sampling sites; c) phosphate stalactites, and lateritic crust composed of jaspilite clasts surrounded by phosphate material (inset 1 for details); d) the floor of Cave N4WS-0067, showing irregular ravines and potholes. 


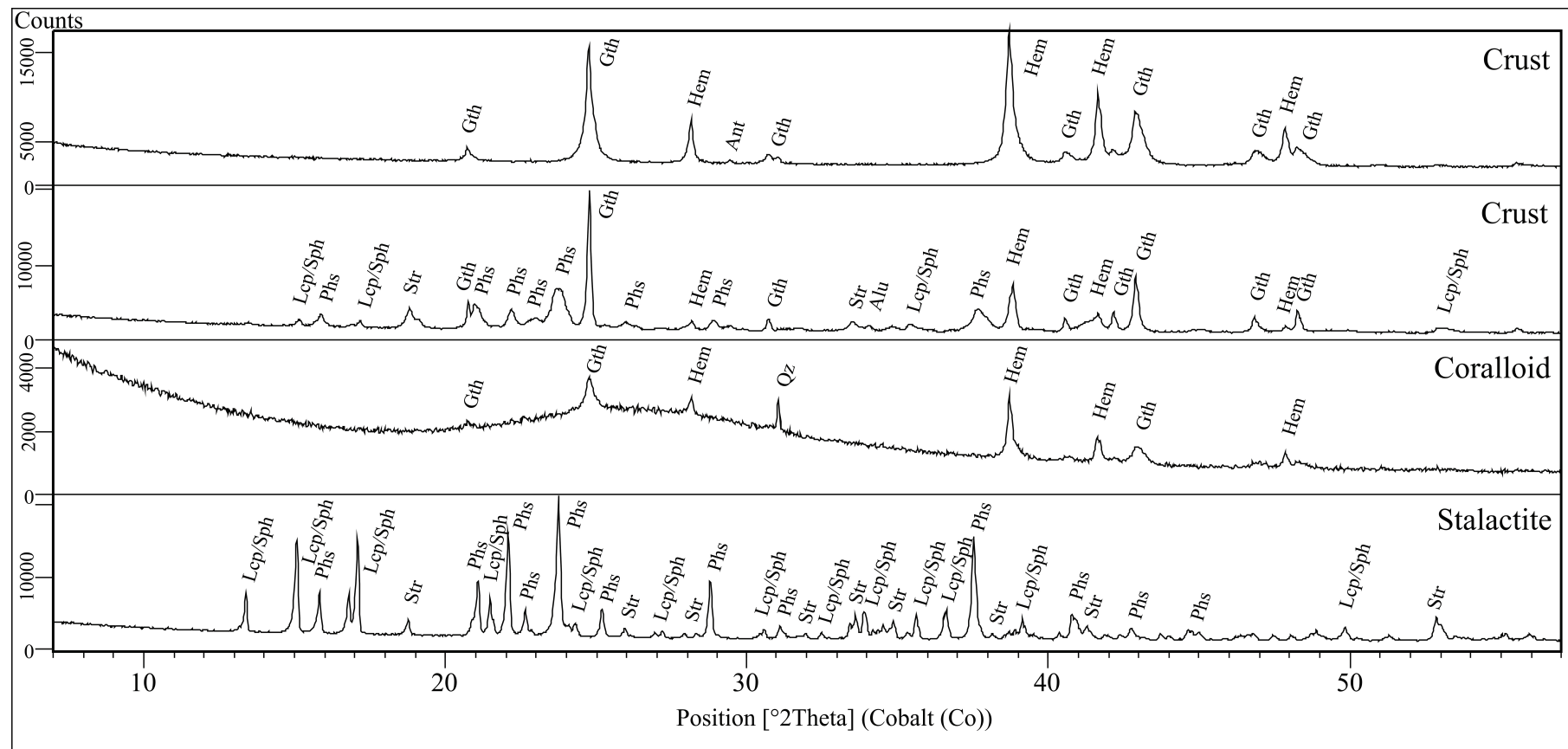

Hem: Hematite; Gth: Goethite; Qz: Quartz; Alu: Alunite; Ant: Anatase; Str: Strengite; Phs: Phosphosiderite; Lcp/Spn: Leucophosphite/Spheniscidite

Fig. 5. Mineralogical composition of the speleothems in Carajás' caves.

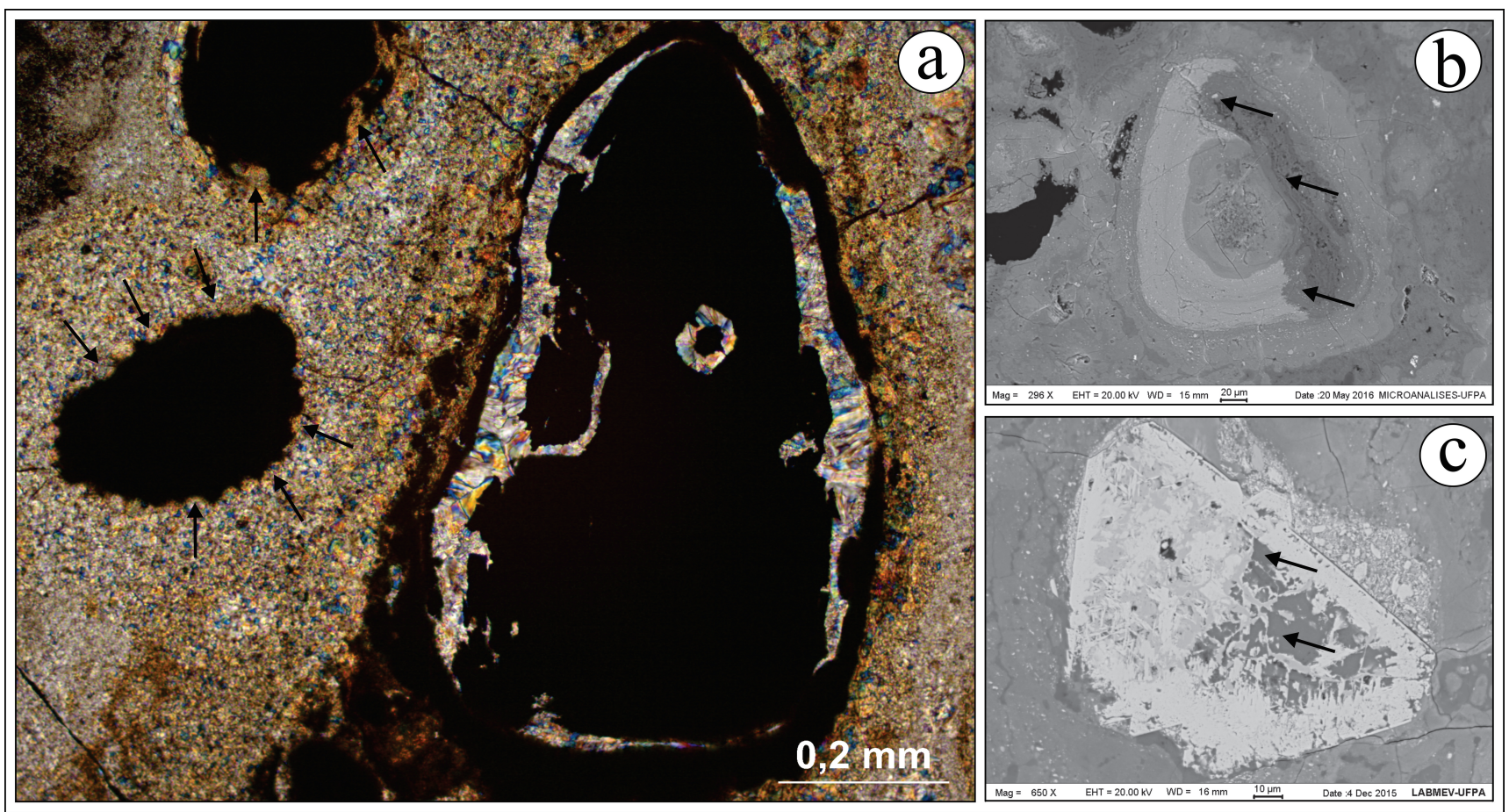

Fig. 6. Lateritic crust with phosphate cement. a) nodules of iron oxide-hydroxides partially cemented and replaced by iron phosphates (X polars); b) iron phosphate partially replacing the core and edges of a goethite nodule (SEM-BSE); c) pseudomorph hematite after magnetite with its core replaced by phosphorus (SEM-BSE).

ammonium is not detectable using EDS and because strengite and phosphosiderite are polymorphs and occur in association. Therefore, based on their general characteristics, strengite, phosphosiderite, leucophosphite, and spheniscidite were described as two groups: strengite-phosphosiderite and leucophosphite-spheniscidite.

Under the light microscope, the strengitephosphosiderite and leucophosphite-spheniscidite crystals appear as cryptocrystalline aggregates, and some display fibrous-radial, prismatic, oolitic and spherulitic habits. These minerals are transparent in their pure forms and are translucent to opaque when mixed with iron hydroxides (Fig. 7c, d). Under SEM-
ES, the strengite-phosphosiderite and leucophosphitespheniscidite differ in that the former displays only a prismatic habit and the latter displays prismatic forms with intergrowths of tabular structures (Fig. 7e, f).

In addition to substitution, direct precipitation can produce iron phosphates as pure speleothems that display fine concentric and uniform layers. Equations 2 and 3 were suggested by Lima \& Reymão (1983) and Scaccia et al. (2002), for this direct precipitation:

$$
\begin{aligned}
& \mathrm{Fe}^{3+}{ }_{(\mathrm{aq})}+\mathrm{H}_{2} \mathrm{PO}_{4(\mathrm{aq})}+2 \mathrm{H}_{2} \mathrm{O}_{(\mathrm{l})} \rightarrow \mathrm{FePO}_{4} \cdot 2 \mathrm{H}_{2} \mathrm{O}_{(\mathrm{s})}+2 \mathrm{H}^{+}{ }_{(\mathrm{aq})} \\
& \mathrm{Fe}^{3+}{ }_{(\mathrm{aq})}+\mathrm{H}_{3} \mathrm{PO}_{4(\mathrm{aq})}+2 \mathrm{H}_{2} \mathrm{O}_{(\mathrm{l})} \rightarrow \mathrm{FePO}_{4} \cdot 2 \mathrm{H}_{2} \mathrm{O}_{(\mathrm{s})}+3 \mathrm{H}^{+}{ }_{(\mathrm{aq})}
\end{aligned}
$$



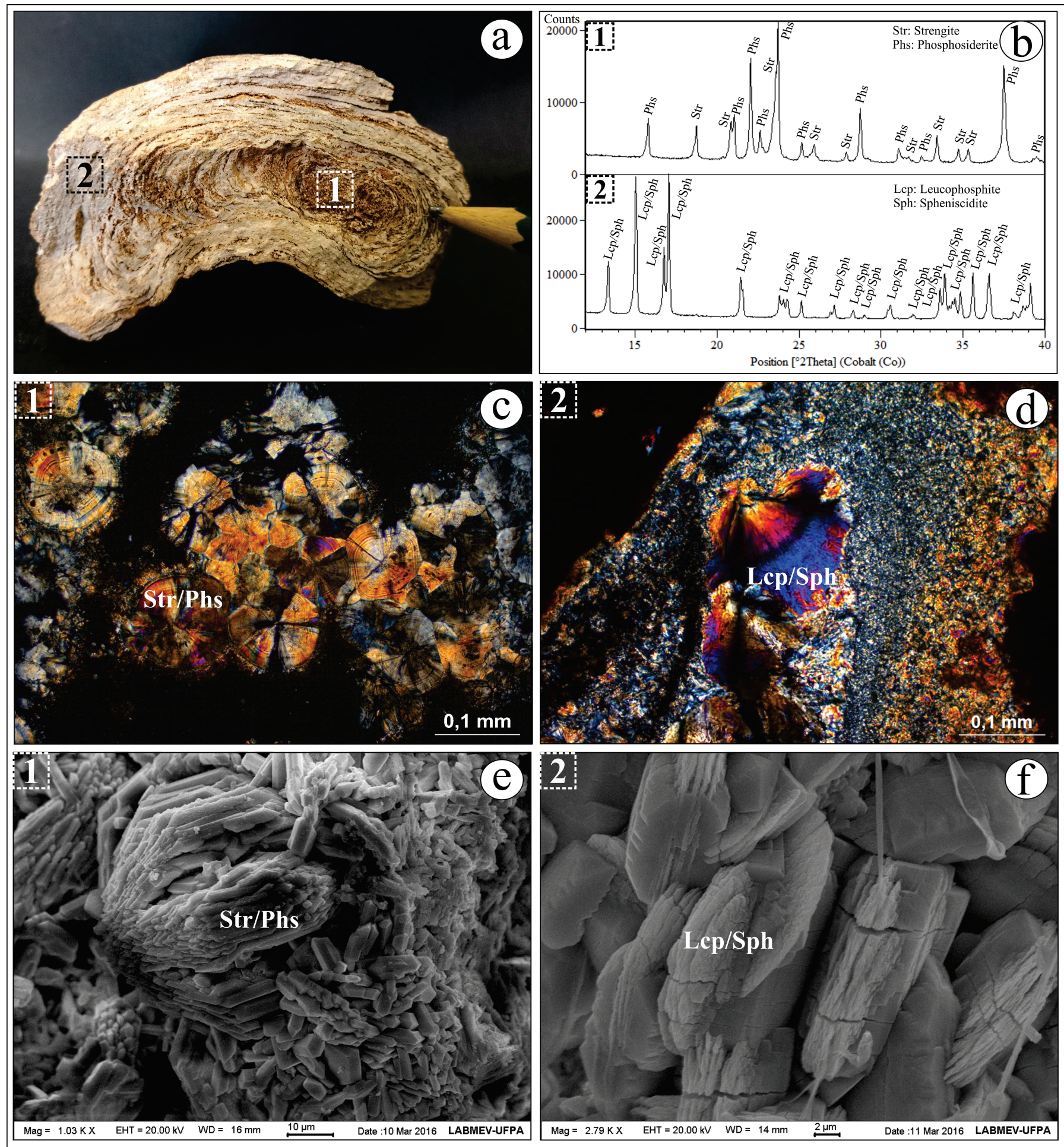

Fig. 7. Micromorphology and mineralogical composition of phosphate speleothems. a) stalactites with concentric layers, composed of strengitephosphosiderite core (inset 1 for details) and leucophosphite-spheniscidite edge (inset 2 for details); b) diffractograms corresponding to the mineralogical composition of phosphate speleothems, with strengite-phosphosiderite core (detail 1) and leucophosphite-spheniscidite edges (detail 2) (Str: strengite, Phs: phosphosiderite, Lcp: leucophosphite, Sph: spheniscidite); c) spherulitic aggregate of nondifferentiated strengitephosphosiderite crystals (X polars); d) nondifferentiated crystals of leucophosphite-spheniscidite with fibrous-radial structures surrounded by cryptocrystalline phosphate (X polars); e) strengite-phosphosiderite crystalline aggregate with prismatic habit (SEM-ES); f) leucophosphitespheniscidite prismatic crystals with intergrowths of tabular crystals (SEM-ES).

\section{Thermal behavior investigation}

\section{Strengite-Phosphosiderite}

The DSC-TG curves for strengite-phosphosiderite speleothems heated from room temperature to $1,000^{\circ} \mathrm{C}$ exhibit four well-defined thermal effects (Fig. 8). According to Arlidge et al. (1963), Nathan et al. (1988), and Reale et al. (2003), these events are as follows:

1) A weak and diffuse endothermic peak at $\sim 100^{\circ} \mathrm{C}$ due to moisture loss, with a mass decrease of $0.9 \%$;
2) An endothermic effect at $207.9^{\circ} \mathrm{C}$ characterized by a large symmetric peak due to removal of two structural water molecules, with a mass loss of $\sim 19.60 \%$. The loss of two $\mathrm{H}_{2} \mathrm{O}$ molecules creates anhydrous minerals, which is followed by structural collapse and formation of semiamorphous mineral phases. This reaction is evident in Fig. 8 as a decline in the DSC baseline following the removal of the $\mathrm{H}_{2} \mathrm{O}$ molecules, which is associated with structural reorganization and 
unit cell shrinkage. These results demonstrate that the amorphization occurs slowly and involves mineral transformations;

3) An exothermic peak at $648.5^{\circ} \mathrm{C}$ attributed to recrystallization and the formation of a new $\mathrm{FePO}_{4}$ compound with low quartz structure;

4) An endothermic effect at $712.8^{\circ} \mathrm{C}$ due to decomposition of $\mathrm{FePO}_{4}$, which is stable only up to $710^{\circ} \mathrm{C}$. The products from heating to $1,000^{\circ} \mathrm{C}$ indicate the formation of $\mathrm{FePO}_{4}$ with high quartz structure, as shown in the diffractograms in Fig. 8.

\section{Leucophosphite-Spheniscidite}

DSC-TG curves for the leucophosphite-spheniscidite samples representing heating from room temperature to $1,000^{\circ} \mathrm{C}$ exhibit well-defined thermal events (Fig. 9). According to Arlidge et al. (1963), Wilson \& Bain (1976), Marincea et al. (2002), Reale et al. (2003), and Yuan et al. (2008), these effects are as follows:

1) A weak and diffuse endothermic peak at $\sim 100^{\circ} \mathrm{C}$ due to moisture loss, with a mass decrease of $0.32 \%$;

2) An endothermic effect at $174.5^{\circ} \mathrm{C}$ representing the removal of one "free" $\mathrm{H}_{2} \mathrm{O}$ molecule, typically from structural cavities. This removal represents a mass loss of $\sim 7.23 \%$, giving the mineral a monohydrated character without structural rearrangement;

3) An endothermic peak at $236.9^{\circ} \mathrm{C}$ associated with the removal of the second $\mathrm{H}_{2} \mathrm{O}$ molecule, with a mass loss of $4.43 \%$ and the formation of anhydrous minerals that could be reversible if exposed to room temperature and humidity;

4) An endothermic effect at $323.4^{\circ} \mathrm{C}$ associated with the removal of the $\mathrm{OH}^{-}$group followed by the removal of an $\mathrm{NH}_{3}^{-}$group at $400^{\circ} \mathrm{C}$, with a mass loss of $\sim 7.71 \%$. The removal of $\mathrm{OH}^{-}$ and $\mathrm{NH}_{3}{ }^{-}$causes total structural breakdown and, consequently, complete amorphization. These effects demonstrate that leucophosphitespheniscidite can not transform into strengitephosphosiderite by thermal decomposition, because the temperature average in Carajás' caves is $24^{\circ} \mathrm{C}$;

5) Exothermic peaks at $512.8^{\circ} \mathrm{C}$ and $579.9^{\circ} \mathrm{C}$ attributed to recrystallization and formation of $\mathrm{FePO}_{4}$ with low quartz structure;

6) The endothermic effects at $709.9^{\circ} \mathrm{C}$ and $845.2^{\circ} \mathrm{C}$ represent sample decomposition, which led at the end of heat treatment to the formation of a $\mathrm{FePO}_{4}$ compound with high quartz structure, similar to the pattern in the diffractogram in Fig. 8.

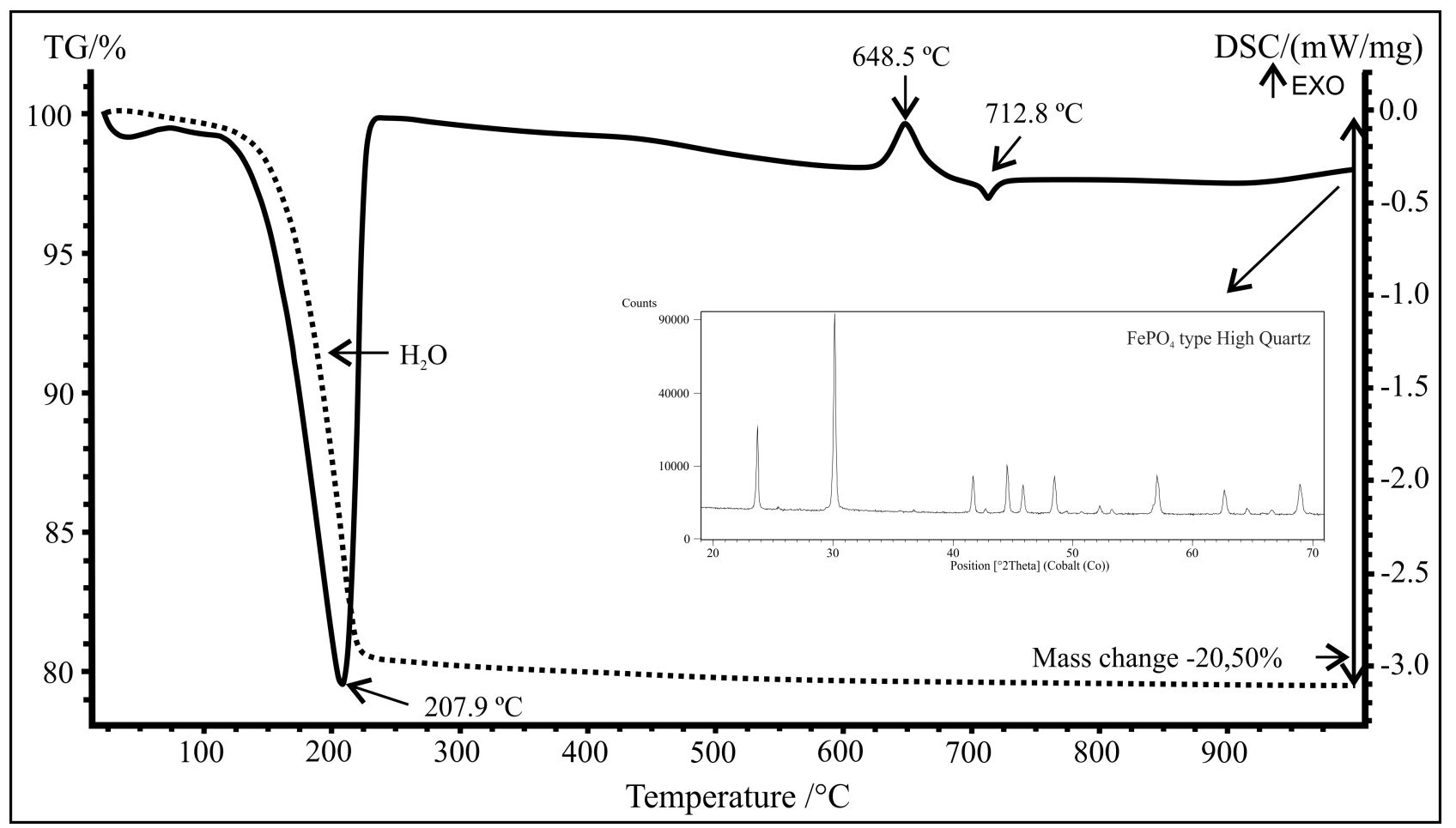

Fig. 8. DSC (solid line) and TG (dotted line) curves for strengite-phosphosiderite minerals and diffractogram corresponding to products from heating to $1,000^{\circ} \mathrm{C}$, indicating the formation of $\mathrm{FePO}_{4}$ with high quartz structure.

Functional groups investigation of iron phosphates

Infrared spectra (Fig. 10) from the samples representing strengite-phosphosiderite and leucophosphite-spheniscidite exhibit absorption bands corresponding to the following functional groups: phosphate $\left(\mathrm{PO}_{4}{ }^{3-}\right)$, hydrophosphate $\left(\mathrm{HPO}_{4}\right)^{2}$, hydroxyl $\left(\mathrm{OH}^{-}\right)$, water $\left(\mathrm{H}_{2} \mathrm{O}\right)$, and ammonium $\left(\mathrm{NH}_{4}\right)$. The following explanations of these spectra are based on findings presented by Marincea et al. (2002), Reale et al. (2003), Dumitraş et al. (2004), Yuan et al. (2008), and Frost et al. (2013).
The medium- to low-intensity absorption bands centered at 3,500 and $3,560 \mathrm{~cm}^{-1}$, respectively, are attributed to asymmetric stretching vibration mode of the $\mathrm{OH}^{-}$group. The medium- to high-intensity bands between 3,100 and $3,380 \mathrm{~cm}^{-1}$ result of symmetric and asymmetric stretching of $\mathrm{H}_{2} \mathrm{O}$ structural group, and the medium- to low-intensity bands between 1,630 and $2,100 \mathrm{~cm}^{-1}$ are attributed to $\mathrm{H}-\mathrm{O}-\mathrm{H}$ in-plane bending.

The (P)O-H stretching absorption band at $2,845 \mathrm{~cm}^{-1}$ and the P-O-H bending bands at 760 and $840 \mathrm{~cm}^{-1}$ are related to the presence of $\left(\mathrm{HPO}_{4}\right)^{2-}$, and the $\mathrm{PO}_{4}{ }^{3-}$ ion is 


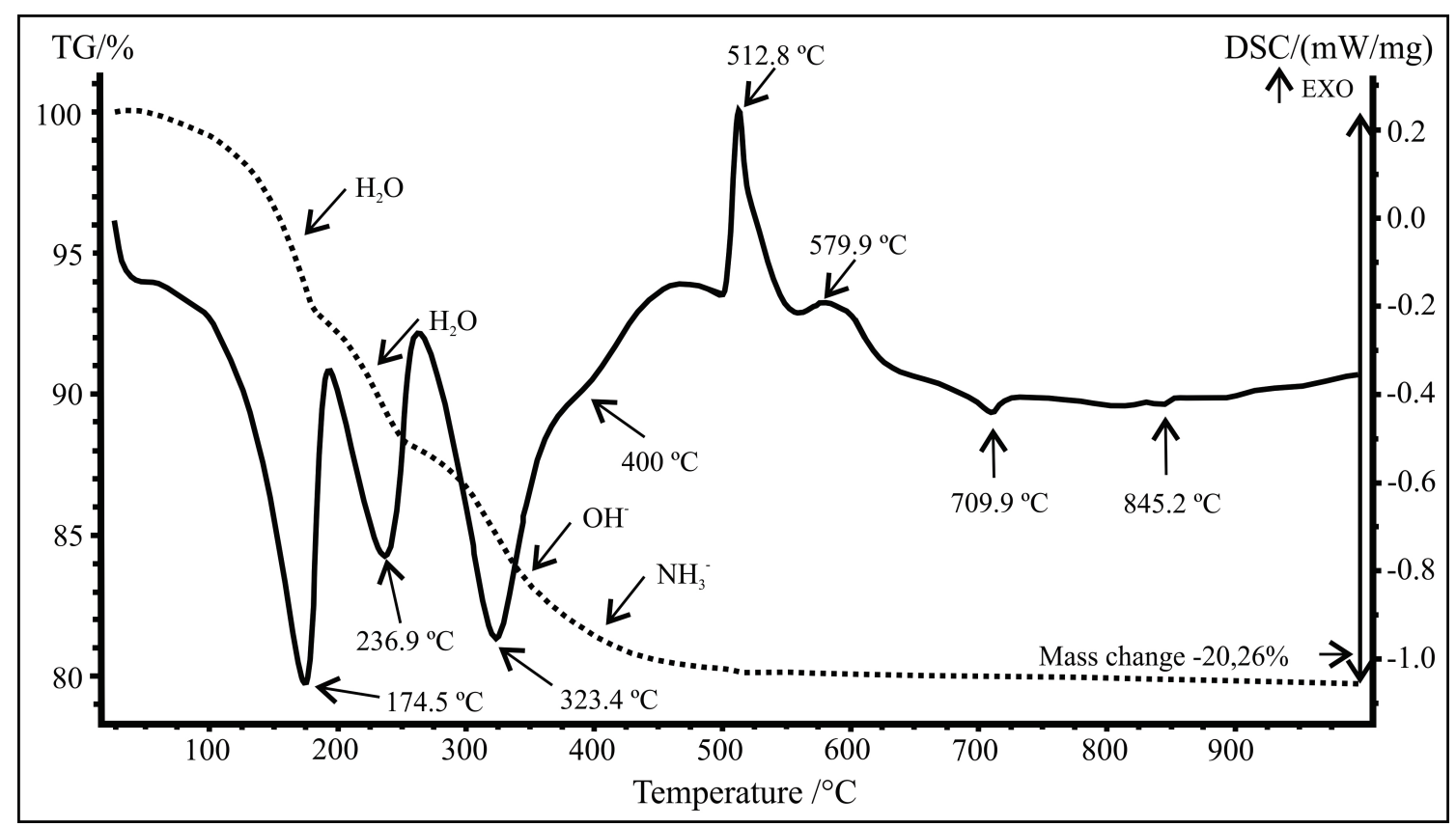

Fig. 9. DSC (solid line) and TG (dotted line) curves for leucophosphite-spheniscidite.

represented by asymmetric stretching bands between 1,010 and $1,150 \mathrm{~cm}^{-1}$ and bending bands at 420, 460, 620 , and $630 \mathrm{~cm}^{-1}$.

$\mathrm{FeO}_{6}$ octahedra are represented by $\mathrm{P}-\mathrm{Fe}-\mathrm{O}$ bending bands between 550 and $595 \mathrm{~cm}^{-1}$. The absorption bands at 1,430 and $3,040 \mathrm{~cm}^{-1}$ correspond to vibration modes of $\mathrm{NH}_{4}$ bending and stretching, respectively, which associated with the other data this research, confirms the presence of spheniscidite.

The spheniscidite mineral was not identified in previous works in Carajás, being probably described as leucophosphite. This is its first occurrence in caves developed in iron ore and lateritic crust. Sauro et al. (2014) first reported the presence of spheniscidite in a cave, however in a quartzitic rock, which was followed by a report of spheniscidite in limestone caves by Wurster et al. (2015). Therefore, this work brings the third occurrence of spheniscidite in cave environment.

\section{Rietveld refinement of spheniscidite}

Crystallographic data from a typical spheniscidite of Cave N4WS-0067 were calculated by Rietveld refinement. The refined parameters included the scale factor, sample displacement, polynomial function with four background coefficients, Thompson-CoxHastings (TCH) profile function (Thompson et al., 1987) with three additional asymmetry coefficients, unit cell parameters, allowable atomic positions and $\mathrm{Y}$ parameter of the TCH function, given that the small size of the crystals was the microstructural parameter that contributed the most to peak broadening.

Fig. 11 shows the overlapping X-ray diffractograms measured and calculated for the spheniscidite. Crystallographic data obtained by Yakubovich \& Dadashov (1992) for synthetic spheniscidite (ICSD 39654) were used as initial values $(a=9.819 \AA$, $b=9.737 \AA, c=9.874 \AA, \beta=102.82^{\circ}$, and the $P 2_{1} / n$

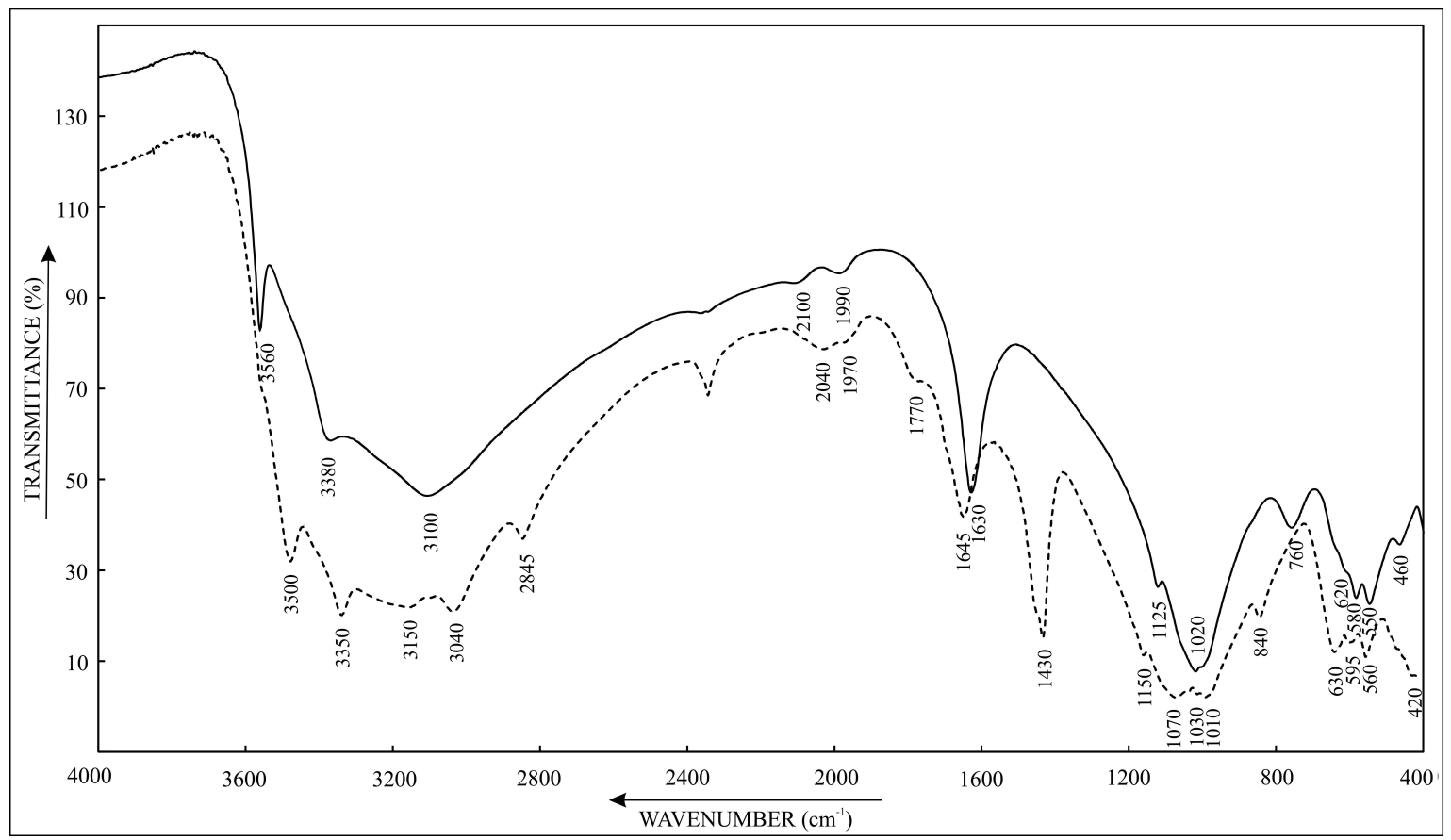

Fig. 10. FTIR analyses of strengite-phosphosiderite (solid line) and leucophosphite-spheniscidite (dotted line). 
space group) and $-0.02224 \mathrm{~mm}$ value for the sample displacement correction. The unit cell parameters calculated for the spheniscidite (1) were slightly smaller than their initial values (2) and those of a second reference (3) cited by Cavellec et al. (1994). Shortening of the unit cell $b$ axis of the spheniscidite (1) is likely due to substitution of $\mathrm{K}^{+}$for $\mathrm{NH}_{4}^{+}$, and the substitution of $\mathrm{Al}^{3+}$ for $\mathrm{Fe}^{3+}$ may have caused the decreases in all the other lattice parameters (Marincea et al., 2002).

The unit cell parameters values estimated for spheniscidite were satisfactory since the statistical indices of refinement $\left(R_{\text {Bragg }}, R_{w p}, R_{\text {exp }}\right.$, and $\left.x^{2}\right)$ were acceptable, considering that $x^{2}=\left(R_{w p} / R_{\text {exp }}\right)^{2}$ and $R_{\text {Bragg }}$ were less than 5, 4.54, and 3.69, respectively. The graphical analysis shows a very good fit for the whole diffractogram, considering that the relatively high difference value $\left(\sim 17^{\circ} 2 \theta,<10 \%\right.$ in the most intense peak) can be acceptable, since the available structural model is from a synthetic spheniscidite. In this case, synthesis conditions are quite different from natural conditions of spheniscidite formation in caves.

The Rietveld refinement also allowed us to estimate the spheniscidite $d$ spacing $\left(\mathrm{d}_{\text {cal }}\right)$ and relative intensities $\left(\mathrm{I}_{\text {cal }}\right)$, which are presented in Table 1 .

\section{Geochemical contribution of guano}

Table 2 presents the mean chemical composition values (major, minor, trace, and rare-earth elements) for the samples of phosphate speleothems (PS), phosphatized laterite (PL), and lateritic crust and jaspilite saprolite (LC/JS) compared to jaspilite samples analyzed by Macambira \& Schrank (2002).

The lateritic crust and jaspilite saprolite were grouped because they compose the cave host rock and exhibit geochemical similarities. The phosphatized laterite, which occurs locally, has a geochemical similarity with the pure phosphate speleothems, however, the detrital iron oxide-hydroxides preserve similarities with host rocks (Table 2).

The mean $\mathrm{P}_{2} \mathrm{O}_{5}$ content, LOI values and $\mathrm{Zn}, \mathrm{Ni}$, and $\mathrm{Rb}$ concentrations were significantly greater in the speleothems and phosphatized laterite samples than in the other samples. This enrichment suggests an allochthonous source, given that the cave host rocks are not a potential source of these elements. In contrast, the high $\mathrm{Fe}_{2} \mathrm{O}_{3}$ levels were inherited from the cave host rocks, which consist of lateritic crust and/or saprolite of rocks belonging to the Grão-Pará Group (Table 2).

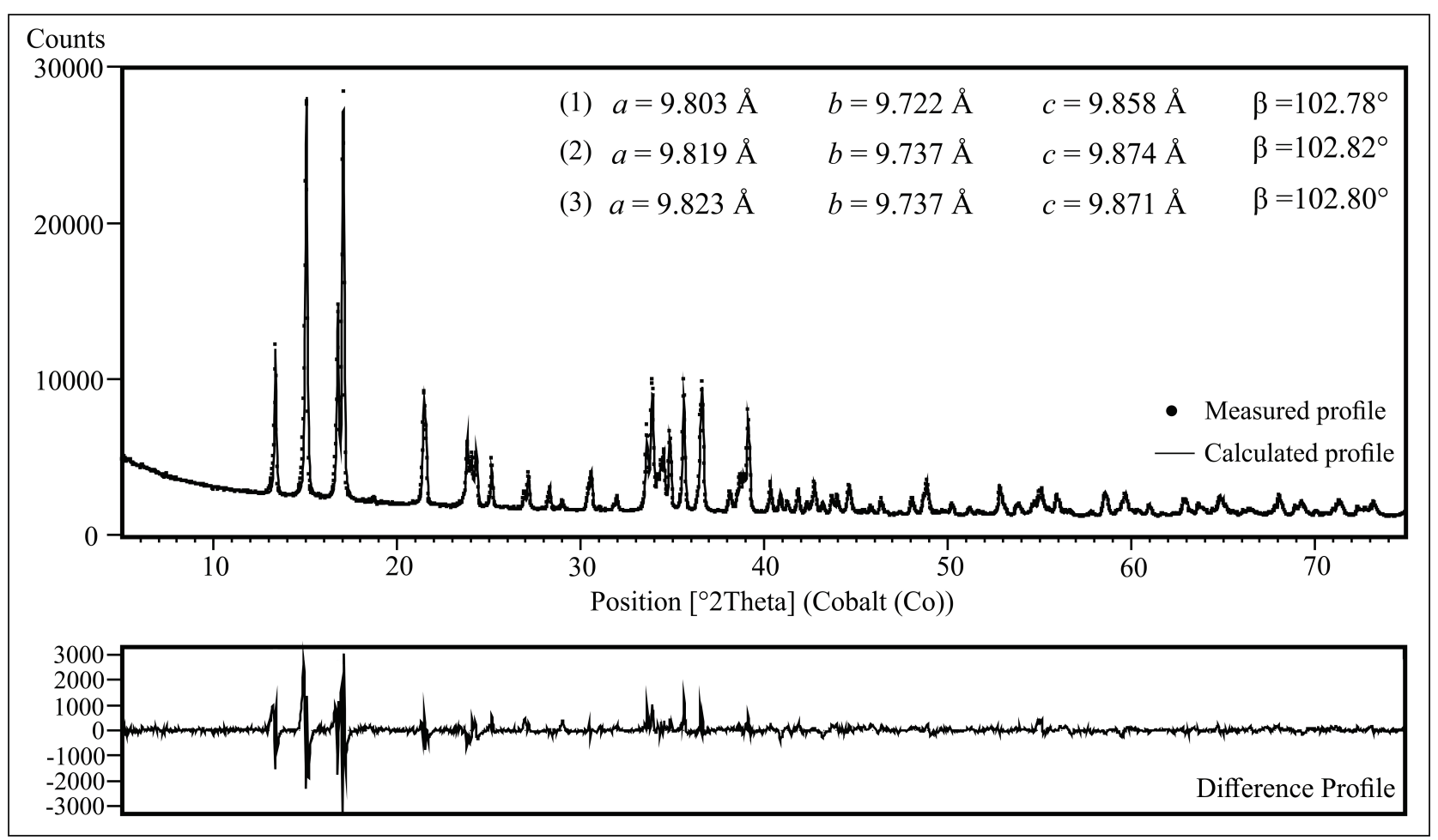

Fig. 11. Graphic representation of Rietveld refinement showing the difference profile, overlap of X-ray diffractograms measured (dotted line) and calculated (solid line) for spheniscidite, and unit cell parameters calculated for the spheniscidite (1) and initial values for the synthetic spheniscidite provided by Yakubovich \& Dadashov (1992) (2) and by Cavellec et al. (1994) (3).

The $\mathrm{P}_{2} \mathrm{O}_{5}$ increase is related to the presence of guano in the caves, given that organic-rich bat guano, in addition to being composed of carbon, nitrogen and sulfur, also contain high content of phosphorus released due to organic reactions in acidic conditions (Hutchinson, 1950; McKelvey, 1967; Forti, 2001; Onac et al., 2002; Zdanowski et al., 2005; Albarède, 2009; Onac \& Forti, 2011; Tămaş et al., 2011).

The transition metals $\mathrm{Zn}$ and $\mathrm{Ni}$, found in high concentrations in samples PS and PL (Table 2), confirm the geochemical signatures of guano in the phosphate minerals (Tatur, 1989; Tatur \& Keck, 1990;
Zdanowski et al., 2005; Liu et al., 2008; Oliveira et al., 2009; Wurster et al., 2015). High content Rb were also detected, which may be another guano geochemical signature, given that the LC/SJ samples are poor in this element. According to Oliveira et al. (2009) and Wurster et al. (2015), metals are concentrated in bat excrements by bioaccumulation along its food chain either by insects or plants intake.

Phosphate speleothem formation in Carajás' caves

Fig. 12 shows the relationship between guano production from bat colonies and phosphate mineral 
Table 1. X-ray powder diffraction data of spheniscidite.

\begin{tabular}{|c|c|c|c|c|c|c|c|c|c|c|c|}
\hline No. & $\mathbf{h}$ & $\mathbf{k}$ & 1 & $\mathbf{d}_{\mathrm{cal}}(\AA \stackrel{\AA}{ })$ & $I_{\text {cal }}(\%)$ & No. & $\mathbf{h}$ & $\mathbf{k}$ & 1 & $\mathbf{d}_{\text {cal }}(\AA)$ & $I_{\text {cal }}(\%)$ \\
\hline 1 & $\overline{1}$ & 0 & 1 & 7.6823 & 37.8 & 43 & 2 & 3 & 1 & 2.5046 & 5.8 \\
\hline 2 & 0 & 1 & 1 & 6.8363 & 60.0 & 44 & $\overline{2}$ & 3 & 2 & 2.4770 & 2.4 \\
\hline 3 & 1 & 1 & 0 & 6.8171 & 49.5 & 45 & 3 & 2 & 1 & 2.4541 & 9.2 \\
\hline 4 & 1 & 0 & 1 & 6.1344 & 45.0 & 46 & 0 & 4 & 0 & 2.4307 & 2.6 \\
\hline 5 & $\overline{1}$ & 1 & 1 & 6.0278 & 100.0 & 47 & 0 & 0 & 4 & 2.4035 & 4.6 \\
\hline 6 & 0 & 0 & 2 & 4.8070 & 22.7 & 48 & 4 & 0 & 0 & 2.3902 & 2.5 \\
\hline 7 & 2 & 0 & 0 & 4.7804 & 19.2 & 49 & $\overline{1}$ & 1 & 4 & 2.3880 & 2.5 \\
\hline 8 & 0 & 2 & 1 & 4.3383 & 5.7 & 50 & 0 & 4 & 1 & 2.3566 & 5.3 \\
\hline 9 & 1 & 2 & 0 & 4.3334 & 10.1 & 51 & 3 & 3 & 0 & 2.2724 & 45 \\
\hline 10 & 0 & 1 & 2 & 4.3091 & 5.9 & 52 & $\overline{1}$ & 2 & 4 & 2.1974 & 4.9 \\
\hline 11 & 2 & 1 & 0 & 4.2899 & 10.8 & 53 & 2 & 2 & 3 & 2.1702 & 2.7 \\
\hline 12 & $\overline{1}$ & 1 & 2 & 4.2577 & 7.6 & 54 & 0 & 4 & 2 & 2.1692 & 2.4 \\
\hline 13 & $\overline{2}$ & 1 & 1 & 4.2437 & 10.6 & 55 & 1 & 1 & 4 & 2.1623 & 8.1 \\
\hline 14 & $\overline{1}$ & 2 & 1 & 4.1080 & 12.5 & 56 & $\overline{4}$ & 1 & 3 & 2.1072 & 3.9 \\
\hline 15 & $\overline{2}$ & 0 & 2 & 3.8412 & 4.8 & 57 & 4 & 2 & 1 & 2.0104 & 4.2 \\
\hline 16 & 1 & 2 & 1 & 3.8101 & 8.9 & 58 & $\overline{3}$ & 3 & 3 & 2.0093 & 5.8 \\
\hline 17 & 2 & 1 & 1 & 3.6567 & 5.8 & 59 & 3 & 1 & 3 & 2.0010 & 3.2 \\
\hline 19 & 2 & 2 & 0 & 3.4085 & 5.2 & 60 & 2 & 0 & 4 & 1.9788 & 2.5 \\
\hline 20 & $\overline{1}$ & 2 & 2 & 3.3923 & 8.8 & 61 & 3 & 4 & 1 & 1.9459 & 3.2 \\
\hline 21 & $\overline{3}$ & 0 & 1 & 3.2473 & 3.0 & 62 & 0 & 4 & 3 & 1.9367 & 6.0 \\
\hline 22 & $\overline{1}$ & 1 & 3 & 3.0943 & 21.5 & 63 & 3 & 4 & 0 & 1.9327 & 3.0 \\
\hline 23 & 0 & 3 & 1 & 3.0712 & 15.1 & 64 & $\overline{4}$ & 0 & 4 & 1.9206 & 2.5 \\
\hline 24 & 1 & 3 & 0 & 3.0694 & 2.5 & 65 & $\overline{4}$ & 3 & 2 & 1.9069 & 7.6 \\
\hline 25 & 1 & 2 & 2 & 3.0692 & 10.8 & 66 & $\overline{5}$ & 0 & 3 & 1.8299 & 2.8 \\
\hline 26 & 2 & 2 & 1 & 3.0639 & 13.4 & 67 & 4 & 2 & 2 & 1.8283 & 5.6 \\
\hline 27 & 0 & 1 & 3 & 3.0436 & 7.0 & 68 & 2 & 5 & 0 & 1.8012 & 2.7 \\
\hline 28 & 3 & 1 & 0 & 3.0284 & 10.8 & 69 & $\overline{4}$ & 3 & 3 & 1.7965 & 5.4 \\
\hline 29 & $\overline{2}$ & 2 & 2 & 3.0139 & 15.3 & 70 & $\overline{3}$ & 4 & 3 & 1.7630 & 4.4 \\
\hline 30 & $\overline{1}$ & 3 & 1 & 2.9861 & 22.0 & 71 & 3 & 1 & 4 & 1.7152 & 4.6 \\
\hline 31 & 2 & 1 & 2 & 2.9251 & 36.0 & 72 & 1 & 2 & 5 & 1.6956 & 3.1 \\
\hline 32 & 1 & 0 & 3 & 2.8542 & 10.9 & 73 & $\overline{5}$ & 3 & 1 & 1.6773 & 2.8 \\
\hline 33 & $\overline{2}$ & 1 & 3 & 2.8534 & 9.5 & 74 & $\overline{1}$ & 5 & 3 & 1.6706 & 3.2 \\
\hline 34 & $\overline{3}$ & 1 & 2 & 2.8464 & 26.0 & 75 & $\overline{3}$ & 5 & 1 & 1.6683 & 4.8 \\
\hline 35 & 1 & 1 & 3 & 2.7386 & 6.1 & 76 & 0 & 0 & 6 & 1.6023 & 3.0 \\
\hline 36 & $\overline{1}$ & 2 & 3 & 2.7099 & 3.0 & 77 & $\overline{3}$ & 3 & 5 & 1.5974 & 4.2 \\
\hline 37 & $\overline{3}$ & 2 & 1 & 2.7003 & 10.9 & 78 & 1 & 3 & 5 & 1.5798 & 2.6 \\
\hline 38 & 0 & 3 & 2 & 2.6872 & 8.7 & 79 & 5 & 3 & 1 & 1.5741 & 5.0 \\
\hline 39 & $\overline{2}$ & 3 & 1 & 2.6712 & 25.7 & 80 & $\overline{3}$ & 1 & 6 & 1.5582 & 2.7 \\
\hline 40 & 2 & 2 & 2 & 2.5940 & 8.9 & 81 & $\overline{6}$ & 2 & 2 & 1.5400 & 3.1 \\
\hline 41 & $\overline{3}$ & 0 & 3 & 2.5608 & 5.7 & 82 & $\overline{1}$ & 6 & 2 & 1.5332 & 3.2 \\
\hline 42 & $\overline{3}$ & 2 & 2 & 2.5387 & 3.0 & 83 & 1 & 6 & 2 & 1.4996 & 3.5 \\
\hline
\end{tabular}

formation as observed in N4WS-0067 and N4WS0072 caves. Fig. 12 also shows the main formation processes of phosphate minerals and their enrichment in metals, particularly $\mathrm{Zn}, \mathrm{Ni}$, and $\mathrm{Rb}$.

Allochthonous components $\left(\mathrm{PO}_{4}, \mathrm{NH}_{4}, \mathrm{Zn}, \mathrm{Ni}\right.$, and $\mathrm{Rb})$ related to the formation of phosphate minerals in caves developed on ferriferous rocks may originate from rapid decomposition of bat guano. Bacterial decomposition of freshly guano releases high amounts of $\mathrm{NH}_{3}$, while phosphorus and certain metals accumulate as residues (McKelvey, 1967; Bridge, 1973; McFarlane et al., 1995; Forti, 2001; Zdanowski et al., 2005; Onac \& Forti, 2011; Wurster et al., 2015).

Phosphorus in acid solutions that percolate through the lateritic substrate produces dissolution and, concomitantly, total or partial replace of iron hydroxides, typically amorphous. Metals such as $\mathrm{Zn}, \mathrm{Ni}$, and $\mathrm{Rb}$ that bioaccumulate in guano are equally assimilated into the neominerals during the phosphatization (Liu et al., 2008; Oliveira et al., 2009; Wurster et al., 2015).

The presence of spheniscidite, leucophosphite, strengite, and phosphosiderite, in addition to indicate acidic $\mathrm{pH}$, cave temperatures and high humidity during their formation, may also suggests changes in local atmospheric of ammonia concentrations, given that spheniscidite formation is dependent on ammonium $\left(\mathrm{NH}_{4}\right)$ availability, which is in turn a product of the reaction between ammonia $\left(\mathrm{NH}_{3}\right)$ and water (Albarède, 2009). Such shifts in ammonia 
Table 2. Chemical analysis of phosphate speleothems (PS), phosphatized laterite (PL), and lateritic crust/jaspilite saprolite (LC/ $\mathrm{SJ}$ ) of the Carajás' caves, in comparison to the banded iron formation (BIF) chemical composition (Macambira \& Schrank, 2002).

\begin{tabular}{|c|c|c|c|c|}
\hline$\%$ & PS & PL & LC/SJ & BIF \\
\hline $\mathrm{SiO}_{2}$ & $<0.01$ & 0.43 & 2.76 & 44.60 \\
\hline $\mathrm{Al}_{2} \mathrm{O}_{3}$ & 0.63 & 0.78 & 0.85 & 0.63 \\
\hline $\mathrm{Fe}_{2} \mathrm{O}_{3}$ & 43.20 & 61.16 & 91.13 & 53.96 \\
\hline $\mathrm{MgO}$ & 0.13 & 0.08 & $<0.01$ & 0.1 \\
\hline $\mathrm{MnO}$ & 0.01 & 0.03 & 0.05 & 0.06 \\
\hline $\mathrm{CaO}$ & $<0.01$ & $<0.01$ & $<0.01$ & 0.04 \\
\hline $\mathrm{Cr}_{2} \mathrm{O}_{3}$ & $<0.01$ & $<0.01$ & $<0.01$ & - \\
\hline $\mathrm{Na}_{2} \mathrm{O}$ & 0.02 & 0.01 & 0.01 & 0.04 \\
\hline $\mathrm{K}_{2} \mathrm{O}$ & 0.62 & 0.29 & 0.03 & 0.02 \\
\hline $\mathrm{TiO}_{2}$ & 0.09 & 0.23 & 0.13 & 0.02 \\
\hline $\mathrm{P}_{2} \mathrm{O}_{5}$ & 38.23 & 23.74 & 0.60 & 0.01 \\
\hline $\mathrm{NH}_{4}$ & 2.33 & - & - & - \\
\hline $\mathrm{LOI}_{1000^{\circ} \mathrm{C}}$ & 15.98 & 13.49 & 2.94 & 0.73 \\
\hline \multicolumn{5}{|l|}{$\mathrm{ppm}$} \\
\hline $\mathrm{Ba}$ & 55.33 & 37.5 & 64.33 & 29.73 \\
\hline Co & $<0.5$ & 0.62 & 2.27 & 11.1 \\
\hline $\mathrm{Cs}$ & $<0.05$ & $<0.05$ & 0.08 & - \\
\hline $\mathrm{Cu}$ & 30.25 & 47.0 & 52.25 & 29.79 \\
\hline $\mathrm{Ga}$ & 8.0 & 8.05 & 3.57 & 21.16 \\
\hline $\mathrm{Hf}$ & 0.96 & 1.30 & 0.67 & - \\
\hline $\mathrm{Nb}$ & 1.42 & 2.84 & 2.25 & - \\
\hline $\mathrm{Ni}$ & 16.0 & 11.0 & 6.25 & 7.83 \\
\hline $\mathrm{Rb}$ & 43.02 & 20.45 & 0.65 & - \\
\hline Th & 2.62 & 3.62 & 2.77 & - \\
\hline $\mathrm{U}$ & 0.17 & 0.59 & 0.30 & - \\
\hline $\mathrm{V}$ & 46.0 & 73.5 & 61.25 & - \\
\hline $\mathrm{Y}$ & 1.43 & 3.05 & 4.10 & - \\
\hline $\mathrm{Zn}$ & 542.25 & 331.25 & 18.0 & 66.68 \\
\hline $\mathrm{Zr}$ & 53.0 & 61.5 & 32.0 & 16.89 \\
\hline Mo & 3.25 & 3.75 & $<2.0$ & - \\
\hline Sn & 0.4 & 0.67 & $<0.3$ & - \\
\hline $\mathrm{W}$ & 0.95 & 1.67 & 1.27 & - \\
\hline$\Sigma$ REE & 21.05 & 36.94 & 35.77 & - \\
\hline
\end{tabular}

Note: values preceded by "<" denote values below the method detection limit; "-" indicates data not available. concentration are indicated by the compositional zoning of the pure-phosphate speleothems, which exhibit strengite-phosphosiderite core and leucophosphite-spheniscidite edges. This zoning can also be related to leucophosphite-spheniscidite thermal decomposition. However, as shown by the DSC-TG curves (Fig. 9), dehydroxylation and loss of $\mathrm{NH}_{3}$ from spheniscidite require temperatures higher than $250^{\circ} \mathrm{C}$.

The presence of phosphate speleothems is expected on cave floors and less commonly on the walls when guano is assumed to be the main source of phosphorus. Thus, the speleothems on the cave ceiling can be explained by inversion of paleofloor for ceiling during the evolution of the caves. This process includes intense dissolution and erosion of the floor caused by meteoric water and acid solutions, followed by the collapse of the former ceiling, resulting in the preservation and expansion of halls at under levels.

\section{CONCLUSIONS}

The phosphate speleothems are the most abundant of Carajás ${ }^{\prime}$ caves. The main phosphate minerals described are strengite, phosphosiderite, leucophosphite, and also spheniscidite. This is the third occurrence of spheniscidite in cave environment and the first in caves developed in iron ore and lateritic crust.

The presence of spheniscidite was confirmed mainly by FTIR analyses, which show absorption bands at 1,430 and $3,040 \mathrm{~cm}^{-1}$ corresponding to $\mathrm{NH}_{4}$ vibration modes. The thermal analyses confirmed that the compositional zoning of the phosphate speleothems could not be formed by thermal decomposition of leucophosphitespheniscidite, since the dehydroxylation and loss of $\mathrm{NH}_{3}$ from these minerals require temperatures higher than $250^{\circ} \mathrm{C}$. The unit cell parameters calculated for the spheniscidite were slightly smaller than those reported by other researches, probably due to increasing substitution of $\mathrm{K}^{+}$for $\mathrm{NH}_{4}^{+}$, and of $\mathrm{Al}^{3+}$ for $\mathrm{Fe}^{3+}$.

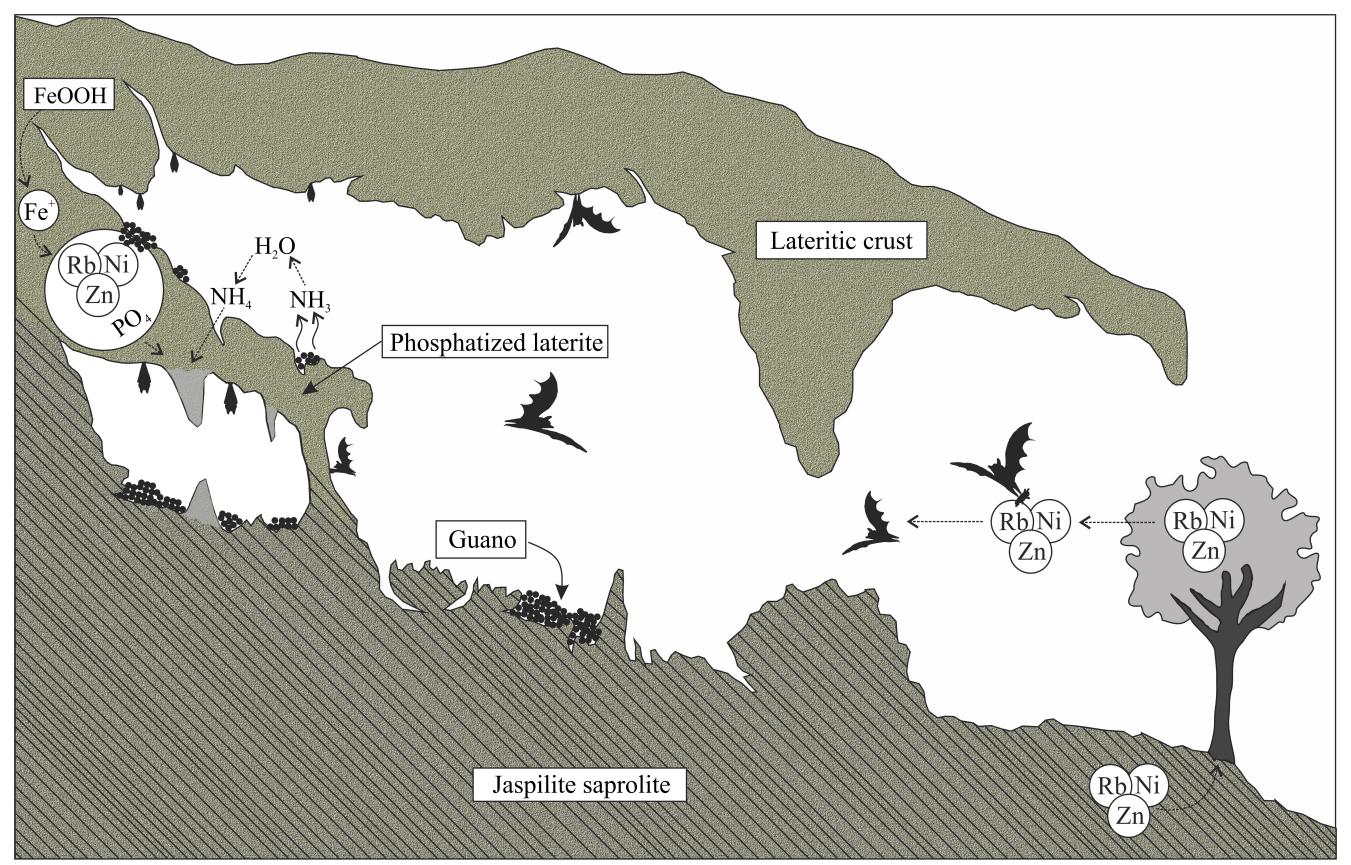

Fig. 12. Schematic cartoon of a typical cave developed in ferriferous rocks from Carajás inhabited by bats and illustration of the main processes of phosphate mineral formation and metal enrichment. 
Iron phosphate minerals of the Carajás' caves resulted from phosphatization of the lateritic crust and/or jaspilite saprolite, caused by acid solutions from guano bacterial decomposition. In addition to $\mathrm{PO}_{4}$ and $\mathrm{NH}_{4}$, the geochemical signature of guano that is preserved in the phosphate minerals was identified based on high content of $\mathrm{Zn}$, Ni and $\mathrm{Rb}$ that bioaccumulated in the bat guano.

Therefore, this research corroborates previous studies that indicated that guano is the main phosphorus source to phosphate speleothems formation, and it represents a new occurrence of spheniscidite in caves. The present study paves the way for new research into caves developed in ferriferous rocks, contributes to the inventory and relevance-based classification of these ecosystems, and highlights the need to preserve caves N4WS-0067 and N4WS-0072 due to their significant mineralogical and speleological value.

\section{ACKNOWLEDGEMENTS}

We thank the research group named "Levantamento Geoespeleológico de Cavidades Naturais da Unidade Espeleológica de Carajás, Província Mineral de Carajás - PROCAV"; Carlos Teles and Rafael Guimarães from VALE S.A for their assistance with the field work; the Programa de Pós-Graduação em Geologia e Geoquímica of the Universidade Federal do Pará - PPGG/UFPA for the use of their laboratory; collaborators from the Laboratório de Caracterização Mineral - LCM/ UFPA; the Coordenação de Aperfeiçoamento de Pessoal de Nivel Superior - CAPES for the master's degree scholarship for the first author; the Brazilian agency CNPq (Conselho Nacional de Desenvolvimento Científico e Tecnológico) is also acknowledged for a grants to the second author (305.392/2014-0). We thank three anonymous reviewers and Dr. Bogdan P. Onac who kindly suggested improvements to the original text that led to an improved manuscript.

\section{REFERENCES}

Albarède F. (Ed.), 2009 - Geochemistry: An introduction, Cambridge University Press, 330 p. https://doi.org/10.1017/CBO9780511807435

Arlidge E.Z., Farmer V.C., Mitchell B.D. \& Mitchell W.A., 1963 - Infra-red, X-ray and thermal analysis of some aluminium and ferric phosphates. Journal of Applied Chemistry, 13: 17-27.

https://doi.org/10.1002/jctb.5010130104

Auler A.S., Piló L.B., Parker C.W., Senko J.M., Sasowsky I.D. \& Barton H.A., 2014 - Hypogene cave patterns in iron ore caves: convergence of forms or processes? In: Klimchouk A., Sasowsky I.D., Mylroie J., Engel S.A. \& Engel A.S. (Eds.), Hypogene cave morphologies. Karst Waters Institute, p. 15-19.

Auler A.S. \& Piló L.B., 2015 - Caves and mining in Brazil: The dilemma of cave preservation within a mining context. In: Andreo B., Carrasco J.J.D., Jiménez P. \& LaMoreaux J.W. (Eds.), Hydrogeological and environmental investigations in karst systems. Springer, p. 487-496.

https://doi.org/10.1007/978-3-642-17435-3 55
Axelrod J.M., Carron M.K., Milton C. \& Thayer T.P., 1952 - Phosphate mineralization at Bomi Hill and Bambuta, Liberia, West Africa. The American Mineralogist, 37 (1112): 883-909.

Boaventura R.S., Rennó C.V., Marita C., Franco E.M.S., Boaventura F.M.C., D'Avila L.M. \& Ventura L.M., 1974 Geomorfologia da Folha SB.22 Araguaia e parte da Folha SC.22 Tocantins, RADAM. Rio de Janeiro, Brasil, 521 p.

Bridge P.J., 1973 - Guano minerals from Murra-el-elevyn Cave Western Australia. Mineralogical Magazine, 39: 467-469.

https://doi.org/10.1180/minmag.1973.039.304.10

Cavellec M., Riou D. \& Ferey G., 1994 - Synthetic spheniscidite. Acta Crystallographica, 50: 1379-1381 https://doi.org/10.1107/S0108270194003896

Dumitrass D., Marincea S. \& Fransolet A.-M., 2004 Brushite in the bat guano from the "dry" Cioclovina Cave (Sureanu Mountains, Romania). Neues Jahrbuch Für Mineralogie, 180: 45-64.

https://doi.org/10.1127/0077-7757/2004/0180-0045

Forti P., 2001 - Biogenic speleothems: an overview. International Journal of Speleology, 30: 39-56. https://doi.org/10.5038/1827-806X.30.1.4

Frost R.L., Xi Y., Scholz R., Belotti F.M. \& Filho M.C., 2013 - Infrared and Raman spectroscopic characterization of the phosphate mineral Leucophosphite

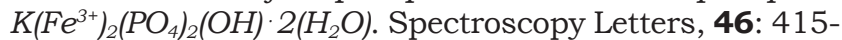
420. https://doi.org/10.1080/00387010.2012.733478

Gálvez N., Barrón V. \& Torrent J., 1999. Preparation and properties of hematite with structural phosphorus. Clay and Clay Minerals, 47: 375-385. https://doi.org/10.1346/CCMN.1999.0470314

Gillieson D.S. (Ed), 1996 - Caves: processes, development, and management. Blackwell Publishers, Oxford, 315 p. https://doi.org/10.1002/9781444313680

Giurgiu A. \& Tămaş T., 2013 - Mineralogical data on bat guano deposits from three Romanian caves. Studia UBB Geologia, 58 (2): 13-18.

https://doi.org/10.5038/1937-8602.58.2.2

Hutchinson G.E., 1950. - Survey of existing knowledge of biogeochemistry. The biogeochemistry of vertebrate excretion. Bulletin of the American Museum of Natural History, 96: 1-554.

Liu X.-D., Sun L.-G., Cheng Z.-Q., Zhao S.-P., Liu K.-X., Wu X.-H., Xie Z.-Q., Yin X.-B., Luo H.-H., Ding X.-F., Fu D.-B. \& Wang Y.-H., 2008 - Paleoenvironmental implications of the guano phosphatic cementation on Dongdao Island in the South China Sea. Marine Geology, 247: 1-16. https://doi.org/10.1016/j.margeo.2007.03.014

Lima W.N. \& Reymão M.F.F., 1983 - Estudo termodinâmico teórico aplicado a gênese e as alterações de hidroxifosfatos naturais: Fosfatos lateriticos de Jandiá (PA) e Pirocaua (MA). Revista Brasileira de Geociências, 13: 41-51.

Macambira J.B. \& Schrank A., 2002 - Quimio-estratigrafia e Evolução dos Jaspilitos da Formação Carajás (Pa). Revista Brasileira de Geociências, 32 (4): 567-578.

Macambira J.B., 2003 - O ambiente deposicional da Formação Carajás e uma proposta de modelo evolutivo para a Bacia Grão Pará. Unpublished PhD dissertation, Instituto de Geociências, Universidade Estadual de Campinas, São Paulo, Brasil, 213 p.

Marincea S., Dumitraş D. \& Gibert R., 2002 - Tinsleyite in the "dry" Cioclovina Cave (Sureanu Mountains, Romania): the second occurrence. European Journal of Mineralogy, 14: 157-164.

https://doi.org/10.1127/0935-1221/2002/0014-0157

Maurity C.W. \& Kotschoubey B., 1995 - Evolução Recente da Cobertura de Alteração no Platô NI-Serra dos CarajásPA. Degradação, pseudocarstificação, espeleotemas. Boletim do Museu Paraense Emílio Goeldi, 7: 331-362. 
McFarlane D.A., Keeler R.C. \& Mizutani H., 1995 Ammonia volatilization in a Mexican bat cave ecosystem. Biogeochemistry, 30: 1-8. https://doi.org/10.1007/BF02181037

McKelvey V.E., 1967 - Phosphate deposits: Contributions to economic geology. Geological Survey Bulletin, 1252D: $13-14$

Nathan Y., Panczer G. \& Gross S., 1988 - The thermal analysis of some phosphate minerals: strengite, lipscombite. cyrilovite and goyazite. Thermochimica Acta, 135: 259-266.

https://doi.org/10.1016/0040-6031(88)87395-7

Oliveira S.M.B., Pessenda L.C.R., Gouveia S.E.M., Fávaro D.I.T. \& Babinski M., 2009 - Evidência geoquímica de solos formados pela interação de guanos com rochas vulcânicas, Ilha Rata, Fernando de Noronha (PE). Geologia USP, Série Científica, 9: 3-12.

https://doi.org/10.5327/Z1519-874X2009000300001

Onac B.P. \& Forti P., 2011 - Minerogenetic mechanisms occurring in the cave environment: an overview. International Journal of Speleology, 40 (2): 79-98. https://doi.org/10.5038/1827-806X.40.2.1

Onac B.P. \& Vereş D.Ş., 2003 - Sequence of secondary phosphates deposition in a karst environment: evidence from Măgurici Cave (Romania). European Journal of Mineralogy, 5: 741-745. https://doi.org/10.1127/0935-1221/2003/0015-0741

Onac B.P., Breban R., Kearns, J. \& Tămaş T., 2002 - Unusual minerals related to phosphate deposits in Cioclovina Cave, Şureanu Mts. (Romania). Theoretical \& Applied Karstology, 15: 27-34.

Parker C.W., Wolf J.A., Auler A.S., Barton H.A. \& Senko J.M., 2013b - Microbial reducibility of Fe(III) phases associated with the genesis of iron ore caves in the iron quadrangle, Minas Gerais, Brazil. Minerals, 3: 395-411. https://doi.org/10.3390/min3040395

Parker C.W., Augusto S.A., Senko J., Sasowsky I.D., Piló L.B., Smith M., Johnston M. \& Barton H., 2013a-Microbial iron cycling and biospeleogenesis: cave development in the carajás formation, brazil. In: Filippi M. \& Bosák P. (Eds.), Proceedings of the $16^{\text {th }}$ International Congress of Speleology, Czech Republic, Brno, 1: 442-446.

Paz S.P.A., Angélica R.S. \& Scheller T., 2012 - X-ray diffration (XRD) studies of kaolinites to support mineralogical quantification of high silica bauxites from the Brazilin Amazon region. In: International Committee for Study of Bauxite, Alumina \& Aluminium - ICSOBA, Proceedings of the $19^{\text {th }}$ International Symposium "Bauxite, Alumina and Aluminium Industry in Brazil and New Global Developments", Belém, Brazil, 40 p.

Piló L.B. \& Auler A., 2009 - Geoespeleologia das cavernas em rochas ferríferas da Região de Carajás, PA. In: Rasteiro M.A. \& Sarmento R.L. (Eds.), 30 Congresso Brasileiro de Espeleologia, Montes Claros, MG, Brasil, 1: 181-186.

Piló L.B., Auler A. \& Martins F., 2015 - Carajás National Forest: Iron ore plateaus and caves in southeastern Amazon. In: Vieira B.C., Salgado A.A.R. \& Santos L.J.C. (Eds.), Landscapes and landforms of Brazil. World Geomorphological Landscapes, Springer, p. 273-283. https://doi.org/10.1007/978-94-017-8023-0_25

Reale P., Scrosati B., Delacourt C., Wurm C., Morcrette M. \& Masquelie C., 2003 - Synthesis and thermal behavior of crystalline hydrated Iron (III) phosphates of interest as positive electrodes in Li batteries. Chemistry of Materials, 15: 5051-5058. https://doi.org/10.1021/cm031107z
Rodriguez-Carvajal J., 1993 - Recent advances in magnetic structure determination by neutron powder diffraction. Physica B, 192: 55-69. https://doi.org/10.1016/0921-4526(93)90108-I

Sauro F., Waele J., Onac B.P., Galli E., Dublyansky Y., Baldoni E. \& Sanna L., 2014 - Hypogenic speleogenesis in quartzite: The case of Corona 'e Sa Craba Cave (SW Sardinia, Italy). Geomorphology, 211: 77-88. https://doi.org/10.1016/j.geomorph.2013.12.031

Scaccia S., Carewska M., Bartolomeo A.D. \& Prosini P.P., 2002 - Thermoanalytical investigation of iron phosphate obtained by spontaneous precipitation from aqueous solutions. Thermochimica, 383: 45-152. https://doi.org/10.1016/S0040-6031(01)00686-4

Simmons G.C., 1963 - Canga caves in the Quadrilátero Ferrifero, Minas Gerias, Brazil. National Speleological Society Bulletin, 25: 66-72.

Simmons G.C., 1964 - Leucophosphite, a new occurrence in the Quadrilatero Ferrifero, Minas Gerais, Brazil. The American Mineralogist, 49: 377-386.

Tatur A., 1989 - Ornithogenic soils of the maritime Antarctic. Polish Polar Research, 10 (4): 481-532.

Tatur A. \& Keck A., 1990 - Phosphates in ornithogenic soils of the Maritime Antarctic. In: Proceeding of the $11^{\text {th }}$ Symposium on Polar Biology, National Institute of Polar Research - NIPR, 3: 133-150.

Tămaş T., Kristály F. \& Barbu-Tudoran L., 2011 Mineralogy of Iza Cave (Rodnei Mountains, N. Romania). International Journal of Speleology, 40 (2): 171-179. https://doi.org/10.5038/1827-806X.40.2.9

Tolbert G.E., Tremaine J.W., Melcher G.C. \& Gomes C.B., 1971 - The recently discovered Serra dos Carajás iron deposits, northern Brazil. Economic Geology, 66: 985-994.

https://doi.org/10.2113/gsecongeo.66.7.985

Vasquez M.L. \& Rosa-Costa L.T., 2008 - Geologia e Recursos Minerais do Estado do Pará: Sistema de Informações Geográficas-SIG: texto explicativo dos mapas Geológico e Tectônico e de Recursos Minerais do Estado do Pará. Escala 1:1.000.000. Relatório Técnico, CPRM, Belém, Brasil.

Wilson M.J. \& Bain D.C., 1976-Occurrence ofleucophosphite in a soil from Elephant Island, British Antarctic Territory. American Mineralogist, 61: 1027-1028.

Wurster C.M., Munksgaard N., Zwart C. \& Bird M., 2015 - The biogeochemistry of insectivorous cave guano: a case study from insular Southeast Asia. Biogeochemistry, 124: 163-175.

https://doi.org/10.1007/s10533-015-0089-0

Yakubovich O.V. \& Dadashov M.S., 1992 - Synthesis, crystal structure of the ammonium analog of leucophosphite $\mathrm{NH}_{4}\left\{\mathrm{Fe}_{2}\left[\mathrm{PO}_{4}\right]_{2}(\mathrm{OH})\left(\mathrm{H}_{2} \mathrm{O}\right)\right\} \cdot \mathrm{H}_{2} \mathrm{O}$. Soviet Physics, Crystallography, 37: 757-760.

Yuan A.Q., Wu J., Huang Z.Y., Wu K., Liao S. \& Tong Zh.F., 2008 - Synthesis of $\mathrm{NH}_{4} \mathrm{FePO}_{4} \cdot \mathrm{H}_{2} \mathrm{O}$ nanoplats via solid-state reaction at low temperature and its thermochemistry properties. Materials Research Bulletin, 43: 1339-1345.

https://doi.org/10.1016/j.materresbull.2007.09.022

Zdanowski M.K., Zmuda M.J. \& Zwolska I., 2005 Bacterial role in the decomposition of marine-derived material (penguin guano) in the terrestrial maritime Antarctic. Soil Biology \& Biochemistry, 37: 581-595. https://doi.org/10.1016/j.soilbio.2004.08.020 